\title{
Özel Gereksinimli Çocuğa Sahip Annelerin Umutsuzluk Düzeyi Tanrı Algısı ve Çocuğunu Kabul-Ret Düzeyleri Arasındaki İlişkinin İncelenmesi ${ }^{1}$
}

\author{
Hamiyet Ece ERDAL ${ }^{2}$ ve Erkan EFILTí ${ }^{3}$
}

$\ddot{O} z$

Bu çalışmanın amacı, özel gereksinimli çocuğa sahip annelerin umutsuzluk düzeyi, tanrı algısı ve çocuğunu kabul-ret düzeyleri arasındaki ilişkinin incelenmesidir. Araştırmanın yöntemi ilişkisel tarama modeli olarak belirlenmiştir. Araştırma da veri toplama aracı olarak Demografik Bilgi Formu, Beck Umutsuzluk Ölçeği, Tanrı Alg1sı Ölçeği ve Ebeveyn Kabul-Red ölçeği kullanılmıştır. Araştırmada 195 anneden veri toplanmıştır. Araştırma bulgularına göre özel gereksinimli çocuğa sahip annelerin Tanr1 alg1sı yükseldikçe umutsuzluğunun azaldığ1 sonucu bulunmuştur. Araştırmada annelerin umutsuzluk düzeyi yükseldikçe anne kabul-ret düzeyinin de yükseldiği görülmektedir. Umutsuzluk alt boyutları ile ebeveyn kabul-ret değişkeni arasındaki ilişkiyi incelendiğinde gelecekten beklenti ile ebeveyn kabul-ret düzeyi arasında anlamlı bir ilişki bulunamamıştır. Annelerin umut düzeyleri yükseldikçe ebeveyn kabul-ret düzeyleri de yükselmektedir. Annelerin Tanrı algıları ve çocuğunu kabul-ret arasındaki ilişkiye bakıldığında annelerin Tanrı algısı ve çocuğunu kabul-ret düzeyleri arasında anlamlı bir ilişki bulunamamıştır. Araştırmanın en önemli sonuçlarından biri olarak; Tanrı algısı umutsuzluğu olumsuz etkilerken, umutsuzluk, ebeveyn kabul-ret düzeyini olumlu yönde etkilemektedir ve Tanrı algısı ile ebeveyn kabul-ret arasında bir ilişki bulunmamıştır.

Anabtar Kelimeler: Umutsuzluk düzeyi, Tanrı alg1sı, Ebeveyn kabul-ret, Özel gereksinimli çocuk

\section{The Investigation of the Relationship between Acceptance-Rejection Level of Their Child, Perception of the God and Hopelessness Level of Mothers of Children with Special Educational Needs}

\begin{abstract}
The aim of this study is to analyze the relationship between the mothers of the children with special needs and mothers' hopelessness level and perception of God, as well as parental acceptance-rejection level. The method of the research was determined as the relational scanning model. To get demographic information about the mothers, Demographic Information Form, Perceptions of God Scale, and Parental Acceptance-Rejection Scale has been used. Data of this research has been collected from 195 mothers. When we look at the relationship between hopelessness level and the perceptions of God of the mothers of the children with special needs, mothers' perception of God tend to increase conversely to their hopelessness. According to the relationship between the hopelessness level and parental acceptance-rejection level of mothers of the children with special needs, this study also determines that as the hopelessness level of mother increases, the level of their acceptance-rejection increases as well. Also, the relationship between perceptions of God and parental acceptance of mothers of the children with special needs does not prove any meaningful relationship. One of the significant outcomes of this research is that perception of God has negative impact on hopelessness while the hopelessness affects parental acceptance-rejection positively, and there is no relationship between perception of God and the parental acceptance and rejection.
\end{abstract}

Key Words: Hopelessness level, Perception of God, Parental Acceptance-rejecetion, Children with special educational needs

Atıf İçin / Please Cite As:

Erdal, H. E. ve Efilti, E. (2021). Özel gereksinimli çocuğa sahip annelerin umutsuzluk düzeyi tanr1 alg1s1 ve çocuğunu kabul-ret düzeyleri arasındaki ilişkinin incelenmesi. Manas Sosyal Araştırmalar Dergisi, 10(1), 199223.

Geliş Tarihi / Received Date: 07.02.2020

Kabul Tarihi / Accepted Date: 24.09.2020

\footnotetext{
${ }^{1}$ Bu çalışma ilk yazarın (HEE), ikinci yazar (EE) danışmanlı̆̆ında yürütülen yüksek lisans tez çalışmasından üretilmiştir

2 Uzman Özel Eğitim Öğretmeni -MEB, heceren88@gmail.com

(D) ORCID: 0000-0003-1869-4509

3 Doç. Dr. - Kırgizistan-Türkiye Manas Üniversitesi Edebiyat Fakültesi, efilti71@gmail.com

(iD ORCID: 0000-0003-1158-5764
} 


\section{Giriş}

Sağlıklı olduğu düşünülen bir bebek dünyaya geldiğinde ailede büyük bir mutluluk ve heyecan yaşanır; fakat bu bebeğin özel gereksinimleri hatta yetersizlikleri olan bir bebek olduğunun öğrenilmesi ile duyulan mutluluk yerini büyük bir şaşkınlık, şok ve kedere bırakır. Gelişimsel yetersizliği olan çocuğa sahip olan aileler genellikle sağlıklı gelişen çocuğu olan ailelere göre çok daha farklı, büyük sorunlarla ilgilenmek ve zorlayıc1 sorumluluklar üstlenmek durumunda kalmaktadırlar. Böylece özellikle ebeveynler kısıtlayıcı ve doyum alınamayan, yalnızca zorluklarla baş edilen bir yaşam sürmelerine sebep olmaktadır (Karaçengel, 2007, s. 1).

Firat (2000) evde engelli bir çocuğun varlığı ve ona ihtiyaç duyduğu bakımı yeterli düzeyde sağlayabilme çabası aileye çok büyük ve ağır bir sorumluluk yüklemektedir. Özellikle anneler bu durumdan çok daha fazla etkilenmektedir. Annelerin psikolojik ve duygusal durumları incelendiğinde özel gereksinimli bir çocuğa sahip olmanın annelik görevini yerine getirebilme durumu üzerinde olumsuz bir etki yarattığı, babanın günlük yaşamına kıyasla annenin günlük yaşamını daha fazla etkilediği ortaya çıkmıştır. Çocuğun ihtiyaçlarının doğurduğu gereksinimler ve bakımına yönelik sorumluluğun neredeyse tamamını anneler üstlendiği için, annelerin çocuk bakımı ve annelik dışındaki hayatlarından vazgeçtikleri ya da kısıtladıkları görülmüştür (Karaçengel, 2007, s. 2).

Annelerin özel gereksinimli çocukla karşılaştıklarında gösterdikleri ilk tepkiler şok, reddetme, üzüntü, öfke, suçluluk, endişe, anlık duygusal krizler, sorunlardan kaçma, hayal kırıklığı, özgüven ve özsaygıda azalma, gelecek kaygisı, umutsuzluk gibi tepkilerdir (Darıca, Pişkin ve Gümüşçü, 1994, s. 145). Umut kavramı gelecekle ilgili beklenti yönüne dikkat çekerken umutsuzlukta negatif düşünceler vardır. Dolayısıyla umutsuzluk geleceğe dair beklenti olmaması olarak değerlendirilmektedir (Stonlet, 1969 Akt: Olcay, 2016, s. 51). Umutsuzluğun bireyin zihninde geleceğe yönelik iyi olmayan, kötü sonuçlanan beklentilere girmek olarak tanımlamıştır. Bu yüzden kötümser ve geleceğe dair umudu olmayan bir kişi hiçbir şeyin düzelmeyeceğine, hiçbir alanda başarılı olamayacağına, geleceğe dair amaçlarını gerçekleştiremeyeceğine ve en kötüsü de sorunlarının hiçbir zaman çözülemeyeceğine inanır (Yıldırım ve Keskinkılıç, Kara, 2017, s. 574).

Bireylerdeki umutsuzluk düzeyini tespit etmek için Beck, Weissman ve Lester (1974) risk gruplarında, "karamsarlığın ölçümü" adlı çalışmaları sonucunda bireylerin umutsuzluk düzeyini belirlemek için "Beck Hopelessness Scale (Beck Umutsuzluk Ölçeği)'ni geliştirmişlerdir. Bu ölçek insanların geleceğe dair olumsuz beklentilerini ölçmeyi amaçlar (Dilbaz ve Seber, 1993, s. 137).

Ailelerin olumsuz duygularla baş edebilmesi, umutsuzluk, stres, çaresizlik ve kaygı düzeylerini kontrol edebilmeleri, yaşamlarına olumlu duygularla devam edebilmeleri için sığındıkları manevi kavramlar vardır. Toplumumuzda güçlü manevi sı̆̆ınak, ebeveynlerin Tanrı alg1sı olarak bilinmektedir. Adler'e (2014, s. 42) göre algı, basit bir fiziki olayı aşan, insanın iç yaşamıyla ilgili en geniş ve kapsamlı bir sonuca ulaşmasını sağlayan ve ruhsal olarak ortaya çıkan bir fonksiyondur. Bir şeye inanmanın verdiği güven insancıl dinlerde Tanrı algısını ve inancını besler. İnanç kişinin kendi duygu ve düşünceleriyle, deneyimleriyle şekillenen bir sistemdir (Fromm, 2004 Akt: Güler, 2007a, s. 12).

Toplumun ya da ebeveynlerin Tanrı algıları, olumlu ve olumsuz yaşantıları değerlendirme durumlarını etkiler. Tanrı algısı, bireyin Tanrı'yı nasıl ögrendiği ve nasıl anlamlandırdığı ile ilgilidir. Tanrı kavramını bilen her birey zihninde Tanrı'ya belirli özellikler yükleyebilir. Olumlu ya da olumsuz olabilen bu özellikler bireyin Tanr1'ya yönelik atıflarıdır (Güler, 2007a, s. 18). Homan ve Cavanaugh (2013, s. 1531), Tanrr'ya yönelik atıfların bireyin yaşamını olumlu yönde etkilemediğini; aksine Tanrı'ya atfedilen bazı özelliklerin birey için faydasız olduğunu belirtmiştir. Sahip olunan Tanrı algısı, bireyin hayatını zorlaştırıp kendisini aciz ve suçlu hissettiriyorsa sorun teşkil etmektedir. Yine aynı şekilde yaşamda karşılaşılan olumsuzluklar Tanır'nın hoşnutsuzluğunun delilleri olarak algılanırsa bu da birey için sıkıntıya neden olabilir(Ceylan, 2018, s. 49).

Bir diğer yanıyla Tanrı'ya dair algıların bazıları da bireyin psikolojik ve sosyal yaşamına fayda sağladığı görülmektedir. Sevgi ve güven yönelimli bir Tanrı algısına sahip bireylerin yaşamı sürdürme, yaşama tutunma ve inançlarına bağllıı nedenlerinin daha fazla olduğu ortaya çıkmıştır. Bireyin yaşadığı stresle başa çıkmada Tanrı'yı güvenilir bir sığınak olarak görmesi, onun merhametine sığınması bireyin yaşamıyla ilgili olumlu düşünmesini sağlamaktadır. Güler, (2007b, s. 14) tarafından yapılan bir çalışmada sevgi ve korku yönelimlerine göre Tanrı algısı olumlu ve olumsuz olarak ikiye ayrılmıştır. Korku eğilimli Tanrı algısında 
"Cezalandıran, Affetmeyen ve Korkutucu Tanr1 ile ilgili ifadeler; sevgi yönelimli Tanr1 algısında ise "Affeden, Çok Seven ve Güvenilir Tanrı" yı niteleyen ifadelere yer verilmiştir.

Çocuğun sosyalleştiği ilk kurum ailedir. Ailede roller ve anne babanın bebeğin gelişimi üzerindeki etkisi, bebek henüz anne karnındayken başlar. Ebeveynlerin yeni bir bebeğin doğumuna hazır olup olmamaları, bebekten ve bebeğin geleceğine dair çok yönlü beklentileri, bebeğin çevresine dair ilk izlenimi ve sosyal, duygusal gelişiminde etkili bir rolü vardır. Birey dünyaya gelip aileye dâhil olduktan sonra ilk etkileşim bebeğin kendi annesiyle olmaktadır. Bebeğin annesi ile olan her türlü fiziksel, sosyal ve duygusal ilişskisi bebeğin çok yönlü gelişimini ve dolayısıyla gelecek yaşamındaki her aşamayı önemli derecede etkileyecektir (Sailor, 2004 Akt: Yakmaz ve Basilgan, 2012, s. 1).

Aileler, sağlıklı bekledikleri çocuklarının gelişimsel yetersizlikle dünyaya gelmesinden sonra durumu kabullenme yeni duruma uyum sağlama sürecinde hem zamana hem de desteğe ihtiyaç duyarlar. Özel gereksinimleri ve yetersizlikleri olan bir çocuğun dünyaya gelişi ile birlikte ailelerin şok, hayal kırıklığı ve üzüntü yaşamaları beklenen duygusal tepkilerdir. Bu süreçten sonra geleceğe dair düşük beklentiler, umutsuzluk, suçluluk duygusu ya da suçlu arama, reddetme süreci yaşanabilir. Kabul; anne-baba ile çocuk arasındaki duygusal ilişkiyi yansıtan bir ebeveyn davranışıdır. Anne babanın çocuğunu kabulü, ona karşı olumlu davranışlar yansıtmasını destekler. Bu davranışlar çocuğuna sevgiyle yaklaşması, olumlu temas, çocuğuna sarılması, istek ve ihtiyaçlarıyla ilgilenmesidir. Çocuğunu reddetme davranışı ise kabullenmedeki olumlu davranışlarının tam tersi olarak yansımadır. Çocuğun ilgi ve ihtiyaçları ile ilgilenmeme, onu dışlama, sürekli eleştirme kıyaslama, sevgiyle yaklaşmama gibi olumsuzlukların çocuğa yansıtılması reddetme davranışılla ilgilidir (Yavuzer, 2000, s. 59).

Literatür çalışmalarında da görüldüğü gibi özel gereksinimli çocuğa sahip ebeveynlerin yalnızca umutsuzluk düzeyleri veya Tanrı algıları veya kabul-ret düzeyleri ile ilgili kavramların tek başına yer aldığ1 çalışmalar yapıldığı görülmektedir. Birbirini ne düzeyde etkilediğiyle ilgili bilgi sahibi olmak için bu üç kavramın bir arada verildiği ve ilişkisinin incelendiği bir çalışma olması açısından bu araştırma önem arz etmektedir. Ailede özel gereksinimli bireyin bakım yükünü taşıyan ve tüm ihtiyaçlarıyla nispeten daha çok ilgilenen kişi anne olduğu için annenin demografik özellikleri de dikkate alınarak annenin umutsuzluk düzeyinin, Tanrı algısının ve çocuğunu kabul-ret düzeyinin bilinmesi ve aralarındaki ilişkinin ne düzeyde olduğunun incelenmesi literatüre önemli katkı sağlayacağı düşünülmektedir.

\section{Amaç}

$\mathrm{Bu}$ araştırmanın amacı özel gereksinimli çocuğa sahip annelerin umutsuzluk düzeyi, Tanrı algısı ve çocuğunu kabul-ret düzeyleri arasındaki ilişkinin incelenmesidir. Bu amaç doğrultusunda belirlenen alt amaçlar şunlardır:

1. Özel gereksinimli çocuğa sahip annelerin umutsuzluk düzeyi, Tanrı algısı ve çocuğunu kabul-ret düzeyleri, annelerin yaşlarına göre anlamlı düzeyde farklılaşmakta mıdır?

2. Özel gereksinimli çocuğa sahip annelerin umutsuzluk düzeyi, Tanrı alg1sı ve çocuğunu kabul-ret düzeyleri, annelerin eğitim düzeylerine göre anlamlı düzeyde farklılaşmakta mıdır?

3. Özel gereksinimli çocuğa sahip annelerin umutsuzluk düzeyi, Tanrı algısı ve çocuğunu kabul-ret düzeyleri, annelerin iş durumuna göre anlamlı düzeyde farklılaşmakta mıdır?

4. Özel gereksinimli çocuğa sahip annelerin umutsuzluk düzeyi, Tanrı alg1sı ve çocuğunu kabul-ret düzeyleri, ailenin aylık gelirine göre anlamlı düzeyde farklılaşmakta mıdır?

5. Özel gereksinimli çocuğa sahip annelerin Tanrı algıları ve umutsuzluk düzeyleri arasında ilişki var mi?

6. Özel gereksinimli çocuğa sahip annelerin umutsuzluk düzeyleri ve çocuğunu kabul- ret düzeyleri arasında ilişki var m?

7. Özel gereksinimli çocuğa sahip annelerin Tanrı algıları ve çocuğunu kabul- ret düzeyleri arasında ilişki var mı?

8. Özel gereksinimli çocuğa sahip annelerin umutsuzluk düzeyi, Tanrı algısı ve çocuğunu kabul-ret düzeyleri arasında anlamlı düzeyde ilişki var mıdır?

\section{Yöntem}

$\mathrm{Bu}$ bölümde araştırmanın modeline, evren ve örneklemine, veri toplama araçlarına, verilerin toplanması ve çözümlenmesine yer verilmiştir. 


\section{Araştırmanın Modeli}

Bu çalışmada özel gereksinimli çocuğa sahip annelerin umutsuzluk düzeyi, Tanrı algısı ve çocuğunu kabul-ret düzeyleri arasındaki ilişkinin incelenmesi amacıyla yapılan bu araştırmanın yöntemi ilişkisel tarama modeli olarak belirlenmiştir. İlişkisel tarama modelleri, iki ve daha çok sayıdaki değişken arasında birlikte değişimin varllğını ve /veya derecesini belirlemede kullanılan bir araştırma modelidir (Karasar, 2007, s. 79). İlişkisel araştırma yöntemi, değişkenler arasındaki ilişkileri belirlemek ve muhtemel sonuçları tahmin için kullanılır. İki ve ya daha fazla değişken arasındaki ilişki düzeyi istatistiksel testler kullanılarak ölçülmeye çalışlır. İlişkinin düzeyini belirlemek için korelasyon testi kullanılır. Korelasyon iki veya daha fazla değişkenin (ayrı ayrı) birlikte tutarlı bir değişim gösterip göstermediğini ortaya koymaktadır (Metin, 2014, s. 107).

\section{Çalışma Grubu}

Araştırma verileri 2018-2019 eğitim-öğretim yllı içerisinde toplanmıştır. Araştırmanın çalışma grubunu Sivas il merkezinde yer alan özel eğitim okulları ve özel eğitim uygulama merkezlerinde eğitim alan hafif/orta/ağır düzeyde yetersizlikten etkilenmiş 928 özel gereksinimli bireyin annelerinden seçilen tesadüfi örnekleme yöntemi kullanılarak seçilmiş 232 anneye ulaşılımıs ve çalışmaya alınmıştır. Ölçeklerin geri dönüşünde bazı eksikliklerden dolayı 37 adet ölçek araştırma dışı bırakılmıştır. Böylece araştırmanın çalışma grubu 195 anneden oluşmuştur. Araştırmaya katılan annelerin yaş değişkenine göre dağllımları; 2635 yaș arası $41(\% 21,03)$ kişi, 36-45 yaş arası $101(\%$ 51,79) kişi ve 46 ve üzeri $53(\% 27,18)$ kişidir. Eğitim durumlarına göre dağılımları; Okuryazar değil/Okuryazar 10 (\% 5,13) kiş̧i, İlköğretim 122 (\% 62,56) kişi, Lise $52(\% 26,67)$ kişi ve Üniversite $11(\% 5,64)$ kişidir. Çalışıp çalışmama durumlarına göre dağılımları: Çalışan $66(\%$ 33,85) kişi, Çalışmayan $129(\%$ 66,15) kişidir. Ailenin aylık gelirine göre dağıllımı: 1500 TL ve altı 27 (\%13,84) kişi, 1501-2500 TL 87 (\%44,62) kişi, 2501-3500 TL 48 (\%24,62) kişi ve 3501 TL ve üzeri $33(\%$ 16,92) kişiden oluşmaktadır.

\section{Veri Toplama Araçları}

Demografik Bilgi Formu: Araştırmaya katılanların demografik özelliklerini belirlemek için hazırlanan Demografik Bilgi Formu kullanılmıştır. Araştırmada kullanılan bu formda annelerin yaşı, eğitim düzeyi, iş durumu (çalışan/çalışmayan), ailenin gelir düzeyi ile ilgili sorular yer almaktadır.

Ebeveyn Kabul Red Ölçĕgi, (EKRÖ/K Ebeveyn formu): Ebeveynlerin çocuklarını kabul ve reddetme düzeylerini belirlemek için Rohner (1978), tarafından geliştirilen Ebeveyn Kabul Red Ölçeği kullanılmıştır. Rohner (1978) tarafından geliştirilen toplam 60 maddeden oluşan ölçeğin 4 alt boyutu olup; Sicaklık ve sevgi (20 ifade), Düşmanlık (15 ifade), Kayıtsızlık ve ihmal (15 ifade), Ayrışmamış reddetme (10 ifade) Ebeveyn reddini ölçen 4 alt ölçeğe 5. alt ölçek olan Kontrol Ölçeğinin eklenmesiyle EKRÖ, Ebeveyn Kabul-Red/ Kontrol Ölçeği (EKRÖ/K Ebeveyn formu) olarak adlandırılarak 73 maddelik son halini almıştır. Ölçek 4'lü Likert tipinde $(1,2,3,4)$ olup sıcaklık ve sevgi ölçeğindeki tüm maddeler tersine puanlanarak düşmanlık, kayıtsızlık ve ihmal, ayrışmamış reddetme ölçeklerinden alınan puanlara eklenir. Böylece, alt testlerden alınan puanlar toplam reddetme puanını verir. Ölçeğinin Türkçe’ye uyarlaması Anjel ve Erkman (1993) tarafından yapılmıştır. Bu araştırmada ölçeğin iç tutarlılık katsayısı 0.90 olarak hesaplanmıştır. EKRÖ/K'nin güvenirlik analizini de Erkman ve Varan (2004 Akt: Öztürk Can ve Aksel, 2017, s. 39) tarafindan yapılmıştır. Ölçeğin geneline ait iç tutarlık katsayısı 0.74 olarak bulunurken sıcaklık; 0.79, düşmanlık; 0.83 , kayıtsızlık ve ihmal; 0.68 , ayrışmamış reddetme; 0.59 ve kontrol alt ölçeğine ait iç tutarlık ise 0.69 şeklinde hesaplanmıştır (Yamaç, 2011, s. 50).

Beck Umutsuəluk Ölçĕğ: Bireylerin umutsuzluk düzeylerini belirlemek için Beck vd. (1974) tarafindan geliştirilen Beck Umutsuzluk Ölçeği (BUÖ) kullanılmıştır. Beck Umutsuzluk Ölçeği, bireyin geleceğe dair olumsuz beklenti seviyesini belirlemek maksadıyla geliştirilmiştir. 20 maddeden meydana gelen ölçek 0-1 arası puanlanmış ve kendini değerlendirme türünde bir ölçektir. Grup olarak da uygulanabilir. Ölçekten alınan puanların yüksekliği, bireydeki umutsuzluğun yüksek olduğunu gösterir. Ölçeğin Türkiye için geçerlik ve güvenirlik çalışması Seber, Dilbaz, Kaptanoğlu ve Tekin (1993, s. 141) tarafindan yapılmıştır. Ölçek, bireyin geleceğe yönelik olumsuz beklentilerini ölçmek amaçlı bir kişilik testidir. Okuma-yazma bilen çocuk, genç ve yetişkinlere zaman sınırlaması olmadan kolay uygulanabilecek bir testtir (Olçay, 2016, s. 72). Ölçek 20 maddeden oluşmaktadır. Gelecekle ilgili duygular; madde 1, 6, 13, 15, 19; güdü kaybı ile ilgili maddeler; madde 2, 3, 9, 11, 12, 16, 17, 20; gelecek beklentisi ile ilgili maddeler; madde 4, 7, 8, 14, 18 olarak belirlenmiştir. Bireyden kendisi için uygun gelen ifadeler için "doğru"; uygun olmayanlar için "yanlış" şıkkının işaretlemesi istenir. On bir "doğru”, dokuz "yanlış" yanıtı içeren ölçek anahtarlarına göre, 
her uyumlu yanıt için ' 1 ' puan, her uyumsuz yanıt için ' 0 ' puan verilir. Elde edilen aritmetik toplam, "umutsuzluk" puanını oluşturur. 0-20 değeri arasında değişebilen puanlar yüksek olduğunda umutsuzluğu, düşük olduğunda umudu gösterir. Ölçek üzerinde daha sonra Durak ve Palabiyıkoğlu (1994, s. 318), tarafından çalışılmış; geçerlik, güvenirlik ve faktör yapısına ilişkin daha ayrıntılı bilgi elde edilmiştir. Ölçek üzerinde geliştirilen faktör analizi sonucunda ölçeğin "gelecekle ilgili duygular ve beklentiler" $(1,3,7,11$ ve 18. maddeler, a =0.78), "motivasyon kaybi" $(2,4,9,12,14,16,17$ ve 20 . maddeler, a $=0.72)$ ve "umut" (5, $6,8,10,13,15$ ve 19. maddeler, a = 0.72) olmak üzere üç faktörden oluştuğu belirtilmiştir (Akt: Eş, 2013, s. 43).

Tanr Algısı Ölçeğ̊: Bireylerin Tanrı'ya yönelik atıflarını belirlemek üzere Güler (2007b, s. 127) tarafindan geliştirilen Tanrı Algisı Ölçeği (TA) kullanılmıştır. Bireyin Tanrı'ya dair duygu, düşünce ve atıflarını ölçmek amacıyla hazırlanan 22 maddeden oluşan ölçeğin maddeleri 5'li Likert tipi şeklinde hazırlanmıştır. Ölçeğin güvenirlik katsayısı .83 olup güvenilir bir ölçek olarak değerlendirilmektedir. Ölçek Tanrı algısını sevgi yönelimli ve korku yönelimli Tanrı algılanı olarak ikiye ayırmışıtır. Buna göre sevgi yönelimli Tanrı algısı seven, şefkatli ve güvenilir bir Tanr1 inancını; korku yönelimli Tanrı algısı ise cezalandıran, affetmeyen, uzak ve korkutucu olan bir Tanrı algısını içermektedir. Ölçek maddelerinin bir kısmı sevgi yönelimli Tanrı'yı bir kısmı da korku yönelimli Tanrı'yı çağrıştırmaktadır. Sevgi yönelimli Tanrı maddeleri $1,4,5,6,9,11,12,13,17,19,20$ ve 22 numaralı ifadeler olan düz; korku yönelimli Tanr1 maddeleri olan $2,3,7,8,10,14,15,16,18$ ve 21 numaralı ifadeler ters puanlanmıştır. Ölçekten 110 ile 22 arası puan alınabilir. Ölçekte yüksek puan sevgi yönelimli Tanrı algısına; düşük puan ise korku yönelimli Tann algisına sahip olunduğunu gösterir.

\section{Verilerin Analizi}

Araştırmada elde edilen veriler SPSS 21,0 kullanılarak analiz edilmiştir. Verileri değerlendirilirken tanımlayıcı istatistiksel metotlar (ortalama, standart sapma, frekans) kullanılmıştır. Sosyal bilimlerde, verilerin normal dağılım olasılığı düşük olduğundan veri setinin çarpıklık ve basıklık değerlerinin kabul edilebilir sınırlarda (-1 ile +1 arası) olması, verilerin normal dağıldığını varsaymak için yeterli görülmektedir (Tabachnick ve Fidell, 2013, s. 78). Araştırma ölçeklerinin çarpıklık ve basıklık katsayıları -1 ile +1 arasında değiştiğinden analizler, verilerin normal dağılım sergilediği varsayımı alında yapılmıştır. Analizlerde, gruplar arası farklılıkların incelenmesi aşamasında, grup varyanslarının homojenliği test edilmiştir. Grup varyanslarının homojen olduğu durumlarda Scheffe testi, homojen olmadığı durumlarda ise Dunnett C testi uygulanmıştır. Ayrıca tek yönlü varyans analizi, bağımsız örneklem t-testi, Korelasyon ve Regresyon analizleri de kullanılmıştır.

\section{Bulgular}

Bu bölümde araştırmanın temel amacı ve alt amaçlarına cevap bulmak için yapılan araştırmanın analizlerinden elde edilen bulgulara ve yorumlara yer verilmiştir. Araştırmanın birinci alt amaçlarından ilki olan özel gereksinimli çocuğa sahip annelerin umutsuzluk düzeyinin annelerin yaşlarına göre farklılık gösterip göstermediğine dair bulgular Tablo 1'de verilmiştir

Tablo 1. Özel Gereksinimli Cocuğa Sabip Annelerin Umutsuəluk Düzeyinin Annelerin Yaşlarna Göre Farklhllk Gösterip Göstermedig̈ine Dair Yapılan Tek Yönlü Varyans Analizi Sonuçlar

\begin{tabular}{|c|c|c|c|c|c|c|}
\hline & & $\overline{\mathrm{KT}}$ & Sd & KO & $\bar{F}$ & $\mathrm{p}$ \\
\hline \multirow{3}{*}{$\begin{array}{l}\text { Geleceğe Yönelik } \\
\text { Duygu/Beklenti }\end{array}$} & Gruplar aras1 & 0,148 & 2 & 0,074 & 1,897 & 0,153 \\
\hline & Gruplar içi & 7,514 & 192 & 0,039 & & \\
\hline & Toplam & 7,662 & 194 & & & \\
\hline \multirow{3}{*}{$\begin{array}{l}\text { Motivasyon } \\
\text { Kayb1 }\end{array}$} & Gruplar aras1 & 0,043 & 2 & 0,022 & 0,183 & 0,833 \\
\hline & Gruplar içi & 22,55 & 192 & 0,117 & & \\
\hline & Toplam & 22,593 & 194 & & & \\
\hline \multirow{3}{*}{ Umut } & Gruplar aras 1 & 0,15 & 2 & 0,075 & 1,051 & 0,352 \\
\hline & Gruplar içi & 13,661 & 192 & 0,071 & & \\
\hline & Toplam & 13,811 & 194 & & & \\
\hline \multirow{3}{*}{ Genel Umutsuzluk } & Gruplar aras 1 & 0,008 & 2 & 0,004 & 0,243 & 0,784 \\
\hline & Gruplar içi & 3,195 & 192 & 0,017 & & \\
\hline & Toplam & 3,203 & 194 & & & \\
\hline
\end{tabular}

Tablo 1 incelendiğinde, yapılan tek yönlü varyans analizi sonucuna göre, tüm boyutlar ve genel umutsuzluk düzeyi için p >0,05 olup anlamlı bir farklılık yoktur. Özel gereksinimli çocuğa sahip annelerin umutsuzluk düzeyleri, annelerin yaşlarına göre farklılık göstermemektedir. Araştırmanın ikinci alt 
ERDAL ve EFİLTI

Özel Gereksinimli Çocuğa Sahip Annelerin Umutsuzluk Düzeyi Tanrı Algısı ve Çocuğunu Kabul-Ret Düzeyleri Arasındaki İlişkinin İncelenmesi

amaçlarından ilki olan özel gereksinimli çocuğa sahip annelerin umutsuzluk düzeyinin annelerin eğitim düzeyine göre farklılaşıp farklılaşmadı̆̆ına dair bulgular Tablo 2'de verilmiştir.

Tablo 2. Özel Gereksinimli Cocuğa Sahip Annelerin Umutsuzluk Düzeyinin Annelerin Ë̆̈itim Düzeyine Farkhlaşıp Farklulaşmadiğına Göre Yapılan Tek Yönlü Varyans Analiz̨i Sonucları

\begin{tabular}{|c|c|c|c|c|c|c|}
\hline & & KT & sd & KO & $F$ & $\mathrm{p}$ \\
\hline \multirow{3}{*}{$\begin{array}{l}\text { Geleceğe Yönelik } \\
\text { Duygu/Beklenti }\end{array}$} & Gruplar aras1 & 072 & 3 & ,024 & ,607 & 612 \\
\hline & Gruplar içi & 7,590 & 191 & 040 & & \\
\hline & Toplam & 7,662 & 194 & & & \\
\hline \multirow{3}{*}{$\begin{array}{l}\text { Motivasyon } \\
\text { Kayb1 }\end{array}$} & Gruplar aras1 & 806 & 3 & 269 & 2,354 & 073 \\
\hline & Gruplar içi & 21,787 & 191 & 114 & & \\
\hline & Toplam & 22,593 & 194 & & & \\
\hline \multirow{3}{*}{ Umut } & Gruplar aras1 & 293 & 3 & ,098 & 1,381 & 250 \\
\hline & Gruplar içi & 13,517 & 191 & 071 & & \\
\hline & Toplam & 13,811 & 194 & & & \\
\hline \multirow{3}{*}{ Genel Umutsuzluk } & Gruplar aras1 & ,141 & 3 & 047 & 2,940 & ,034 \\
\hline & Gruplar içi & 3,061 & 191 & 016 & & \\
\hline & Toplam & 3,203 & 194 & & & \\
\hline
\end{tabular}

Tablo 2 incelendiğinde, yapılan tek yönlü varyans analizi sonucuna göre genel umutsuzluk düzeyi için p $<0,05$ olup anlamlı bir farklılık vardır. Geleceğe Yönelik Duygu/Beklenti, Motivasyon Kayb1 ve Umut alt boyutlarında $\mathrm{p}>0,05$ düzeyde olup anlamlı farklılık olmamasına karşın özel gereksinimli çocuğa sahip annelerin genel umutsuzluk düzeyleri, annelerin eğitim düzeyine göre farklılık göstermektedir. Genel umutsuzluk düzeyi için grup varyansları homojen olmadığından $(p=0,034>0,05)$, gruplar arası farklılıkların incelenmesi aşamasında, Scheffe testi uygulanmıştır ve Tablo 3 'te verilmiştir.

Tablo 3. Genel Umutsuzluk Düzeyine Iliş̧kin Scheffe Testi Sonuçlar

\begin{tabular}{|c|c|c|c|}
\hline & & Ortalama Farkı & Standart Hata \\
\hline \multirow{3}{*}{ Okuryazar/değil } & İlköğretim &,- 07844 &, 04164 \\
\hline & Lise &,- 08787 & ,04372 \\
\hline & Üniversite &,$- 16224^{*}$ & ,05532 \\
\hline \multirow{3}{*}{ İlköğretim } & Okuryazar/değil & 07844 &, 04164 \\
\hline & Lise &,- 00943 & ,02097 \\
\hline & Üniversite &,- 08380 & ,03986 \\
\hline \multirow{3}{*}{ Lise } & Okuryazar/değil & ,08787 & ,04372 \\
\hline & İlköğretim &, 00943 & ,02097 \\
\hline & Üniversite &,- 07437 & ,04202 \\
\hline \multirow{3}{*}{ Üniversite } & Okuryazar/değil &, $16224^{*}$ & ,05532 \\
\hline & İlköğretim & ,08380 & ,03986 \\
\hline & Lise & 07437 & ,04202 \\
\hline
\end{tabular}

${ }^{*} \cdot \mathrm{p}<0,05$

Tablo 3 incelendiğinde, analiz sonucuna göre, okuryazar olan/olmayan katıllimcılar ile üniversite mezunları arasında anlamlı bir farklılık görülmektedir. Genel umutsuzluk düzeyi bakımından gruplara ait tanımlayıcı istatistikler Tablo 4'te verilmiştir.

Tablo 4. Genel Umutsuqluk Düzeyi Bakımından Gruplara Ait Tanmlayıu İstatistikler

\begin{tabular}{lccc}
\hline Boyutlar & $\mathbf{N}$ & $\overline{\boldsymbol{X}}$ & $\mathbf{S}$ \\
\hline Okuryazar/değil & 10 & 1,3692 &, 15723 \\
İlköğretim & 122 & 1,4477 &, 12432 \\
Lise & 52 & 1,4571 &, 13403 \\
Üniversite & 11 & 1,5315 &, 07261 \\
\hline
\end{tabular}


Tablo 4 incelendiğinde, okuryazar olan/olmayan katılımcıların genel umutsuzluk düzeyinin üniversite mezunları ve diğer gruplardan daha düşük olduğu görülmektedir. Araştırmanın üçüncü alt amaçlarından ilki olan özel gereksinimli çocuğa sahip annelerin umutsuzluk düzeyinin annelerin iş durumuna göre farklılaşıp farklılaşmadığına dair bulgular Tablo 5’te verilmiştir.

Tablo 5. Özel Gereksinimli Çocuğa Sahip Annelerin Umutsuəluk Düzeyinin Annelerin İs Durumuna Göre Farkhlilașip Farkhlasmadiğgna Dair Yapilan t-Testi Sonuçlar

\begin{tabular}{llccccc}
\hline & & \multicolumn{2}{c}{ Varyans Eşitliği İçin } & \multicolumn{3}{c}{ t-testi sonuçları } \\
\cline { 3 - 7 } & & $\mathbf{F}$ & Sig. & $\mathbf{t}$ & $\mathbf{d f}$ & $\mathrm{p}$ \\
\hline Geleceğe Yönelik & Eşit varyans &, 081 &, 776 &,- 542 & 182 &, 588 \\
Duygu/Beklenti & Eşit olamayan varyans & & &,- 546 & 137,058 &, 586 \\
\hline Motivasyon & Eşit varyans &, 627 &, 430 &,- 606 & 182 &, 545 \\
Kayb1 & Eşit olamayan varyans & & &,- 595 & 127,681 &, 553 \\
\hline \multirow{2}{*}{ Umut } & Eşit varyans & 5,457 &, 021 & 2,942 & 182 &, 004 \\
& Eşit olamayan varyans & & & 2,800 & 116,183 & $\mathbf{0 0 6}$ \\
\hline \multirow{2}{*}{ Genel Umutsuzluk } & Eşit varyans & 1,094 &, 297 & 2,223 & 182 & $\mathbf{0 2 7}$ \\
& Eşit olamayan varyans & & & 2,184 & 127,661 & $\mathbf{0 3 1}$ \\
\hline
\end{tabular}

Tablo 5 incelendiğinde, yapılan bağımsız örneklem t-testi sonuçlarına göre, Umut ve Genel Umutsuzluk boyutları için $\mathrm{p}<0,05$ düzeyde olup anlamlı bir farklılık olduğu görülmüştür. Geleceğe Yönelik Duygu/Beklenti ve Motivasyon Kaybı alt boyutları için p $>0,05$ olup anlamlı bir farklılık yoktur. Özel gereksinimli çocuğa sahip annelerin Umut ve Genel Umutsuzluk düzeyleri, annelerin iş durumuna göre anlamlı düzeyde farklılaşmaktadır. Gruplara ait tanımlayıcı istatistikler Tablo 6'da verilmiştir.

Tablo 6. Umut ve Genel Umutsuzluk Bakımmndan Gruplara Ait Tammlayuc İstatistikler

\begin{tabular}{lcccccc}
\hline & & Umut & \multicolumn{3}{c}{ Genel Umutsuzluk } \\
\hline Boyutlar & $\mathbf{N}$ & $\overline{\boldsymbol{X}}$ & $\mathbf{S}$ & $\mathbf{N}$ & $\overline{\boldsymbol{X}}$ & $\mathbf{S}$ \\
\hline Çalış1yor & 66 & 1,343 & 0,292 & 66 & 1,477 & 0,129 \\
Çalışmiyor & 118 & 1,224 & 0,244 & 118 & 1,435 & 0,121 \\
\hline
\end{tabular}

Tablo 6 incelendiğinde, çalışan annelerin umut alt boyutu ve genel umutsuzluk düzeylerinin çalışmayanlara göre daha yüksek olduğu görülmektedir. Araştırmanın dördüncü alt amaçlarından ilki olan özel gereksinimli çocuğa sahip annelerin umutsuzluk düzeyinin annelerin gelir durumuna göre farklılaşıp farklılaşmadığına dair bulgular Tablo 7'de verilmiştir.

Tablo 7. Özel Gereksinimli Cocuğa Sahip Annelerin Umutsuzluk. Düzeyinin Annelerin Ayllk. Gelirine Göre Farkhlașşp Farkhlassmadığına Dair Yapılan Tek Yönlü Varynas Analiz̨i Sonuçlar

\begin{tabular}{|c|c|c|c|c|c|c|}
\hline & & KT & sd & KO & $F$ & $\mathrm{p}$ \\
\hline \multirow{3}{*}{ Sevgi Yönelimli } & Gruplar aras1 & 2,904 & 2 & 1,452 & 2,914 & ,057 \\
\hline & Gruplar içi & 95,665 & 192 & ,498 & & \\
\hline & Toplam & 98,569 & 194 & & & \\
\hline \multirow{3}{*}{ Korku Yönelimli } & Gruplar aras1 & ,123 & 2 & 061 &, 166 & 847 \\
\hline & Gruplar içi & 70,899 & 192 & ,369 & & \\
\hline & Toplam & 71,022 & 194 & & & \\
\hline \multirow{3}{*}{ Genel Tanrı Alg1s1 } & Gruplar arası & ,916 & 2 & 458 & 2,889 & ,058 \\
\hline & Gruplar içi & 30,428 & 192 & 158 & & \\
\hline & Toplam & 31,344 & 194 & & & \\
\hline
\end{tabular}

Tablo 7 incelendiğinde, yapılan tek yönlü varyans analizi sonucuna göre, tüm boyutlar için $\mathrm{p}>0,05$ olup anlamlı bir farklıllk bulunamamıştır. Özel gereksinimli çocuğa sahip annelerin Geleceğe Yönelik Duygu/Beklenti, Motivasyon Kaybı, Umut ve Genel Umutsuzluk düzeyleri, ailenin gelir durumuna göre farklılık göstermemektedir. Araştırmanın ikinci alt amaçlarından ilki olan özel gereksinimli çocuğa sahip annelerin tanrı algısının annelerin yaşına göre farklılaşıp farklılaşmadığına dair bulgular Tablo 8'de verilmiştir. 
ERDAL ve EFİLTI

Özel Gereksinimli Çocuğa Sahip Annelerin Umutsuzluk Düzeyi Tanrı Algısı ve Çocuğunu Kabul-Ret Düzeyleri Arasındaki İlişkinin İncelenmesi

Tablo 8. Özel Gereksinimli Çocuğa Sahip Annelerin Tann Algısının Annelerin Yaşına Göre Farklulaşıp Farklulaşmadı̆ğna Dair Yapılan Tek Yönlü Varyans Analiz̨i Sonuçları

\begin{tabular}{|c|c|c|c|c|c|c|}
\hline & & K'T & sd & KO & $\mathbf{F}$ & $\mathrm{p}$ \\
\hline \multirow{3}{*}{ Sevgi Yönelimli } & Gruplar aras1 & 2,904 & 2 & 1,452 & 2,914 & ,057 \\
\hline & Gruplar içi & 95,665 & 192 & ,498 & & \\
\hline & Toplam & 98,569 & 194 & & & \\
\hline \multirow{3}{*}{ Korku Yönelimli } & Gruplar aras 1 & , 123 & 2 & ,061 & , 166 &, 847 \\
\hline & Gruplar içi & 70,899 & 192 & ,369 & & \\
\hline & Toplam & 71,022 & 194 & & & \\
\hline \multirow{3}{*}{ Genel Tanr1 Alg1sı } & Gruplar aras1 & ,916 & 2 &, 458 & 2,889 & ,058 \\
\hline & Gruplar içi & 30,428 & 192 & ,158 & & \\
\hline & Toplam & 31,344 & 194 & & & \\
\hline
\end{tabular}

Tablo 8, incelendiğinde, yapılan tek yönlü varyans analizi sonucuna göre, tüm boyutlar ve genel Tanr1 alg1sı için p >0,05 olup anlamlı bir farklılık bulunamamıştır. Özel gereksinimli çocuğa sahip annelerin Tanrı algılamaları, annelerin yaşlarına göre farklılık göstermemektedir. Araştırmanın ikinci alt amaçlarından ikincisi olan özel gereksinimli çocuğa sahip annelerin Tanrı algısının annelerin eğitim düzeyine göre farklılaşıp farklılaşmadığına dair bulgular Tablo 9'da verilmiştir.

Tablo 9. Özel Gereksinimli Çocuğa Sahip Annelerin Tanr Algisinın Annelerin Eğitim Düzeylerine Göre Farkhlaşıр Farklılaşmadiğına Dair Yapılan Tek Yönlü Varyans Analizi Sonuçlar

\begin{tabular}{llccccc}
\hline & & KT & sd & KO & F & p \\
\hline \multirow{3}{*}{ Sevgi Yönelimli } & Gruplar aras1 & 3,630 & 3 & 1,210 & 2,434 &, 066 \\
& Gruplar içi & 94,939 & 191 &, 497 & & \\
\hline \multirow{3}{*}{ Korku Yönelimli } & Toplam & 98,569 & 194 & & & \\
& Gruplar aras1 & 1,936 & 3 &, 645 & 1,784 & \\
& Gruplar içi & 69,086 & 191 &, 362 & & \\
& Toplam & 71,022 & 194 & & & \\
Genel Tanr1 Alg1s1 & Gruplar aras1 & 1,424 & 3 &, 475 & 3,031 & \\
& Gruplar içi & 29,919 & 191 &, 157 & & \\
\hline
\end{tabular}

Tablo 9 incelendiğinde, yapılan tek yönlü varyans analizi sonucuna göre, genel tanrı alg1s1 için p<0,05 olup anlamlı bir farklılık vardır. Sevgi Yönelimli ve Korku Yönelimli alt boyutları için p $>0,05$ düzeyde anlamlı bir farklılık bulunamamıştır. Özel gereksinimli çocuğa sahip annelerin genel tanrı algılamaları, annelerin düzeyine eğitim göre farklılık göstermektedir. Genel Tanrı alg1sı için grup varyansları homojen olmadığından $(p=0,031>0,05)$, gruplar arası farklılıkların incelenmesi aşamasında, Scheffe testi uygulanmıştır. Test sonuçları Tablo 10'da verilmiştir.

Tablo 10. Genel Tanr Algısına Ilişkin Scheffe Testi Sonuçlar

\begin{tabular}{|c|c|c|c|}
\hline & & Ortalama Fark1 & Standart Hata \\
\hline \multirow{3}{*}{ Okuryazar/değil } & İlköğretim &,- 116 &, 130 \\
\hline & Lise & ,078 & ,136 \\
\hline & Üniversite &,- 061 &, 172 \\
\hline \multirow{3}{*}{ İlköğretim } & Okuryazar/değil & ,116 & ,130 \\
\hline & Lise & ,195* &, 065 \\
\hline & Üniversite &, 054 & ,124 \\
\hline \multirow{3}{*}{ Lise } & Okuryazar/değil &,- 078 & ,136 \\
\hline & İlköğretim &,$- 195^{*}$ &, 065 \\
\hline & Üniversite &,- 140 & ,131 \\
\hline \multirow{3}{*}{ Üniversite } & Okuryazar/değil & ,061 & ,172 \\
\hline & İlköğretim &,- 054 & ,124 \\
\hline & Lise &, 140 & ,131 \\
\hline
\end{tabular}


Tablo 10 incelendiğinde, analiz sonucuna göre, ilköğretim ve lise mezunları arasında anlamlı bir farklılık görülmektedir. Gruplara ait tanımlayıcı istatistikler incelendiğinde ise ilköğretim mezunlarının tanrı alg1sı lise mezunlanında anlamlı bir şekilde daha yüksektir. Genel tanrı alg1sı ile ilgili yapılan analiz Tablo 11'de verilmiştir.

Tablo 11. Genel Tanrı Algısı Bakımından Gruplara Ait Tanımlaynu Istatistikler

\begin{tabular}{lccc}
\hline Boyutlar & N & $\overline{\boldsymbol{X}}$ & S \\
\hline Okuryazar/değil & 10 & 3,1409 &, 60699 \\
İlköğretim & 122 & 3,2575 &, 40612 \\
Lise & 52 & 3,0621 &, 35140 \\
Üniversite & 11 & 3,2025 &, 18671 \\
\hline
\end{tabular}

Tablo 11 incelendiğinde, genel tanrı algısı bakımından en düşük grup lise mezunlarıdır. Araştırmanın üçüncü amaçlanından ikincisi biri olan özel gereksinimli çocuğa sahip annelerin Tannı algısının annelerin iş durumuna göre farklılaşıp farklılaşmadı̆̆ına dair bulgular Tablo 12'de verilmiştir.

Tablo 12. Öẓel Gereksinimli Cocuğa Sahip Annelerin Tanr Algısım Annelerin İs Durumuna Göre Farklalaşıp Farklılaşmadı̆̆ına Dair Yapılan Bağımsız Örneklem T-Testi Sonuçlar

\begin{tabular}{|c|c|c|c|c|c|c|}
\hline & & \multicolumn{2}{|c|}{$\begin{array}{c}\text { Varyans Eşitliği İçin } \\
\text { Levene Testi }\end{array}$} & \multicolumn{3}{|c|}{ t-testi sonuçları } \\
\hline & & $\mathbf{F}$ & Sig. & $t$ & df & $\mathrm{p}$ \\
\hline \multirow{2}{*}{ Sevgi Yönelimli } & Eşit varyans & 11,066 & 001 & $-2,896$ & 182 &, 004 \\
\hline & Eşit olamayan varyans & & & $-2,666$ & 105,635 &, 009 \\
\hline \multirow{2}{*}{ Korku Yönelimli } & Eşit varyans & 1,446 & 231 & $-1,580$ & 182 & ,116 \\
\hline & Eşit olamayan varyans & & & $-1,695$ & 163,153 & 092 \\
\hline \multirow{2}{*}{ Genel Tanrı Algısı } & Eşit varyans & 1,301 & 256 & $-4,015$ & 182 &, 000 \\
\hline & Eşit olamayan varyans & & & $-3,966$ & 129,802 &, 000 \\
\hline
\end{tabular}

Tablo 12 incelendiğinde, yapılan bağımsız örneklem t-testi sonuçlarına göre, Sevgi Yönelimli ve Genel Tanrı Alg1sı boyutları için $\mathrm{p}<0,05$ olup anlamlı bir farklılık bulunmuştur. Korku Yönelimli Tanrı alg1sı için p >0,05 olup anlamlı bir farklılık bulunamamıştır. Özel gereksinimli çocuğa sahip annelerin Sevgi Yönelimli ve Genel Tanrı Algısı, annelerin iş durumuna göre anlamlı düzeyde farklılaşmaktadır. Gruplara ait tanımlayıcı istatistikler Tablo 13'te verilmiştir.

Tablo 13. Sevgi Yönelimli ve Genel Tann Algısı Bakımından Gruplara Ait Tanımlayncı Istatistikler

\begin{tabular}{lcccccc}
\hline & \multicolumn{3}{c}{ Sevgi Yönelimli } & \multicolumn{3}{c}{ Genel Tanrı Algisı } \\
\hline Boyutlar & $\mathbf{N}$ & $\overline{\boldsymbol{X}}$ & $\mathbf{S}$ & $\mathbf{N}$ & $\overline{\boldsymbol{X}}$ & S \\
\hline Çalışyor & 66 & 4,328 &, 845 & 66 & 3,035 &, 397 \\
Çalışmiyor & 118 & 4,645 &, 627 & 118 & 3,273 &, 380 \\
\hline
\end{tabular}

Tablo 13 incelendiğinde, çalışmayan annelerin Sevgi Yönelimli ve Genel Tanrı Algısının çalışanlara göre daha yüksek olduğu görülmektedir. Araştırmanın dördüncü alt amaçlarından ikincisi olan özel gereksinimli çocuğa sahip annelerin tannı algısının annelerin gelirine göre farklılaşıp farklılaşmadığına dair bulgular Tablo 14'de verilmiştir.

Tablo 14. Özel Gereksinimli Cocuğa Sahip Annelerin Tanr Algısının Annelerin Aylık Gelirine Göre Farklılaşı Farkhlaşmadı̆gna Dair Yapılan Tek Yönlü Varyans Analizi Sonuclar

\begin{tabular}{|c|c|c|c|c|c|c|}
\hline & & KT & sd & KO & $\mathbf{F}$ & $\mathrm{p}$ \\
\hline \multirow{3}{*}{$\begin{array}{l}\text { Sevgi } \\
\text { Yönelimli }\end{array}$} & Gruplar aras1 &, 549 & 3 & ,183 & ,356 &, 785 \\
\hline & Gruplar içi & 98,020 & 191 &, 513 & & \\
\hline & Toplam & 98,569 & 194 & & & \\
\hline \multirow{3}{*}{$\begin{array}{l}\text { Korku } \\
\text { Yönelimli }\end{array}$} & Gruplar aras1 & 1,148 & 3 &, 383 & 1,046 &, 373 \\
\hline & Gruplar içi & 69,874 & 191 & ,366 & & \\
\hline & Toplam & 71,022 & 194 & & & \\
\hline \multirow{3}{*}{ Genel Tanr1 Alg1s1 } & Gruplar aras1 & ,715 & 3 & ,238 & 1,485 & 220 \\
\hline & Gruplar içi & 30,629 & 191 &, 160 & & \\
\hline & Toplam & 31,344 & 194 & & & \\
\hline
\end{tabular}


ERDAL ve EFİLTI

Özel Gereksinimli Çocuğa Sahip Annelerin Umutsuzluk Düzeyi Tanrı Algısı ve Çocuğunu Kabul-Ret Düzeyleri Arasındaki İlişkinin İncelenmesi

Tablo 14 incelendiğinde, yapılan tek yönlü varyans analizi sonucuna göre, tüm boyutlar için p>0,05 olup anlamlı bir farklılık olmadığı görülmüştür. Özel gereksinimli çocuğa sahip annelerin Tanrı algılamaları, ailenin gelir durumuna göre farkll1ık göstermemektedir.

Araştırmanın birinci alt amaçlarından üçüncüsü olan özel gereksinimli çocuğa sahip annelerin çocuğunu kabul-ret düzeylerinin annelerin yaşlarına göre farklılaşıp farklılaşmadığına dair bulgular Tablo 15 'te verilmiştir.

Tablo 15. Özel Gereksinimli Cocuğa Sabip Annelerin Çocuğunu Kabul-Ret Düzeylerinin Annelerin Yaşlarma Göre Farklulaşı Farklulaşmadı̆̆na Dair Yapılan Tek Yönlü V aryans Analiz̨i Sonuclar

\begin{tabular}{|c|c|c|c|c|c|c|}
\hline & & KT & sd & KO & F & $\mathrm{p}$ \\
\hline \multirow{3}{*}{ Sicaklık/Sevgi } & Gruplar aras & 1,101 & 2 &, 551 & 3,284 & ,040 \\
\hline & Gruplar içi & 32,192 & 192 &, 168 & & \\
\hline & Toplam & 33,293 & 194 & & & \\
\hline \multirow{3}{*}{ Düşmanlık/Saldırganlık } & Gruplar aras 1 & 2,047 & 2 & 1,024 & 2,817 & 062 \\
\hline & Gruplar içi & 69,755 & 192 &, 363 & & \\
\hline & Toplam & 71,802 & 194 & & & \\
\hline \multirow{3}{*}{ Kayıtsızlı/İhmal } & Gruplar aras 1 & 1,285 & 2 & ,642 & 2,407 & ,093 \\
\hline & Gruplar içi & 51,229 & 192 & 267 & & \\
\hline & Toplam & 52,514 & 194 & & & \\
\hline \multirow{3}{*}{ Ayrışmamış Reddetme } & Gruplar aras & 1,318 & 2 & 659 & 3,523 & ,031 \\
\hline & Gruplar içi & 35,923 & 192 &, 187 & & \\
\hline & Toplam & 37,242 & 194 & & & \\
\hline \multirow{3}{*}{ Kontrol } & Gruplar aras & 031 & 2 & ,016 & ,058 & 944 \\
\hline & Gruplar içi & 52,276 & 192 &, 272 & & \\
\hline & Toplam & 52,307 & 194 & & & \\
\hline \multirow{3}{*}{ Genel Kabul-Ret Düzeyi } & Gruplar aras & 008 & 2 & ,004 & ,243 & ,784 \\
\hline & Gruplar içi & 3,195 & 192 &, 017 & & \\
\hline & Toplam & 3,203 & 194 & & & \\
\hline
\end{tabular}

Tablo 15 incelendiğinde, yapılan tek yönlü varyans analizi sonucuna göre: Sicaklık/Sevgi ve Ayrışmamış Reddetme alt boyutları için $\mathrm{p}<0,05$ olup anlamlı bir farklılık bulunmuştur. Düşmanlık/Saldırganlık, Kayıtsızlık/İhmal ve genel kabul-red düzeyinde p $>0,05$ olduğundan anlamlı bir farklılık yoktur. Özel gereksinimli çocuğa sahip annelerin Sıcaklık/Sevgi ve Ayrışmamış Reddetme düzeyleri, annelerin yaşlarına göre farklılık göstermektedir. Sıcaklık/Sevgi boyutu için grup varyansları homojen olmadı̆̆ından $(\mathrm{p}=0,040<0,05)$, gruplar arası farklılıkların incelenmesi aşamasında, Dunnett C testi uygulanmış ve sonuçlar Tablo 16'da verilmiştir.

Tablo 16. Sucaklık/Sevgi boyutuna Ilişkin Dunnett C Testi Sonuçar

\begin{tabular}{lccc}
\hline & & Ortalama Fark1 & Standart Hata \\
\hline \multirow{2}{*}{$26-35$} & $36-45$ &, 009 &, 075 \\
& $46-55$ &,- 161 &, 085 \\
\hline \multirow{2}{*}{$36-45$} & $26-35$ &,- 009 &, 075 \\
& $46-55$ &,$- 171^{*}$ &, 069 \\
\hline \multirow{2}{*}{$46-55$} & $26-35$ &, 161 &, 085 \\
& $36-45$ &, $171^{*}$ &, 069 \\
\hline
\end{tabular}

Tablo 16 incelendiğinde, analiz sonucuna göre, 36-45 ve 46-55 yaş grupları arasında anlamlı bir farklılık görülmektedir. Gruplara ait tanımlayıcı istatistikler Tablo 17'de verilmiştir.

Tablo 17. Kabul-Ret Bakımından Gruplara Ait Tanmlayı İstatistikler

\begin{tabular}{lccc}
\hline Boyutlar & $\mathbf{N}$ & $\overline{\boldsymbol{X}}$ & $\mathbf{S}$ \\
\hline $26-35$ & 41 & 1.524 & .251 \\
$36-45$ & 101 & 1,514 &, 381 \\
$46-55$ & 53 & 1,686 &, 539 \\
\hline
\end{tabular}


Tablo 17 incelendiğinde, 46-55 yaş grubundaki annelerin Sıcaklık/Sevgi düzeyinin diğer gruplara göre daha yüksek olduğu görülmektedir. Ayrışmamış Reddetme boyutu için grup varyansları homojen olmadığından $(\mathrm{p}=0,031<0,05)$, gruplar arası farklılıkların incelenmesi aşamasinda, Dunnett $\mathrm{C}$ testi uygulanmıştır. Test sonuçları Tablo 18'de verilmiştir.

Tablo 18. Ayrışmamıs Reddetme boyutuna İlişkin Dunnett C Testi Sonuçlar

\begin{tabular}{|c|c|c|c|}
\hline & & Ortalama Farkı & Standart Hata \\
\hline \multirow{2}{*}{$26-35$} & $36-45$ &,- 021 & 080 \\
\hline & $46-55$ & , 168 & ,089 \\
\hline \multirow{2}{*}{$36-45$} & $26-35$ & 021 & ,080 \\
\hline & $46-55$ & ,190* &, 073 \\
\hline \multirow{2}{*}{$46-55$} & $26-35$ &,- 168 & ,089 \\
\hline & $36-45$ &,$- 190^{*}$ & 073 \\
\hline
\end{tabular}

Tablo 18 incelendiğinde, analiz sonucuna göre 36-45 ve 46-55 yaş grupları arasında anlamlı bir farklılık görülmektedir. Gruplara ait tanımlayıcı istatistikler incelendiğinde, Ayrışmamış Reddetme düzeyinin diğer gruplara durumu Tablo 19'da verilmiştir.

Tablo 19: Kabul-Ret Bakımından Gruplara Ait Tammlaync Istatistikler

\begin{tabular}{lccc}
\hline Boyutlar & $\mathbf{N}$ & $\overline{\boldsymbol{X}}$ & $\mathbf{S}$ \\
\hline $26-35$ & 41 & 3,8098 &, 36865 \\
$36-45$ & 101 & 3,8317 &, 37708 \\
$46-55$ & 53 & 3,6415 &, 55934 \\
\hline
\end{tabular}

Tablo 19 incelendiğinde, 36-45 yaş grubundaki annelerin Ayrışmamış Reddetme düzeyinin diğer gruplara göre daha yüksek olduğu görülmektedir. Araştırmanın ikinci alt amaçlarından üçüncüsü olan özel gereksinimli çocuğa sahip annelerin çocuğunu kabul-ret düzeylerinin annelerin eğitim düzeyine göre farklılaşıp farklılaşmadığına dair bulgular Tablo 20'de verilmiştir.

Tablo 20. Özеl Gereksinimli Cocuğa Sahip Annelerin Cocuğunu Kabul-Ret Düzeylerinin Annelerin Eğitim Düreyine Göre Farkhlașip Farkhllașmadiğnna Dair Yapılan Tek Yönlü V aryans Analiẓ Sonuclar

\begin{tabular}{|c|c|c|c|c|c|c|}
\hline & & KT & sd & KO & F & $\mathrm{p}$ \\
\hline \multirow{3}{*}{ Sicaklik/Sevgi } & Gruplar aras1 & 2,265 & 3 &, 755 & 4,647 & ,004 \\
\hline & Gruplar içi & 31,028 & 191 &, 162 & & \\
\hline & Toplam & 33,293 & 194 & & & \\
\hline \multirow{3}{*}{ Düşmanlık/Saldırganlık } & Gruplar aras1 & 1,195 & 3 & ,398 & 1,077 & 360 \\
\hline & Gruplar içi & 70,607 & 191 & ,370 & & \\
\hline & Toplam & 71,802 & 194 & & & \\
\hline \multirow{3}{*}{ Kayitsızlık/İhmal } & Gruplar aras1 & 899 & 3 & 300 & 1,109 & 347 \\
\hline & Gruplar içi & 51,615 & 191 & 270 & & \\
\hline & Toplam & 52,514 & 194 & & & \\
\hline \multirow{3}{*}{ Ayrışmamış Reddetme } & Gruplar aras1 & 849 & 3 & 283 & 1,485 & 220 \\
\hline & Gruplar içi & 36,393 & 191 & ,191 & & \\
\hline & Toplam & 37,242 & 194 & & & \\
\hline \multirow{3}{*}{ Kontrol } & Gruplar arası & 851 & 3 & 284 & 1,054 & ,370 \\
\hline & Gruplar içi & 51,455 & 191 & ,269 & & \\
\hline & Toplam & 52,307 & 194 & & & \\
\hline \multirow{3}{*}{ Genel Kabul-Red Düzeyi } & Gruplar arası & 014 & 3 & ,005 & ,080 & ,971 \\
\hline & Gruplar içi & 11,208 & 191 & ,059 & & \\
\hline & Toplam & 11,222 & 194 & & & \\
\hline
\end{tabular}


Tablo 20 incelendiğinde, yapılan tek yönlü varyans analizi sonucuna göre: Sicaklık/Sevgi boyutu için $\mathrm{p}<0,05$ olup anlamlı düzeyde farklılık olduğu bulunmuştur. Ayrişmamış Reddetme, Düşmanlık/Saldırganlık, Kayıtsızlık/İhmal ve genel kabul-red düzeyinde p>0,05 olduğundan anlamlı düzeyde farklılık bulunamamıstır. Özel gereksinimli çocuğa sahip annelerin Sıcaklık/Sevgi düzeyleri, annelerin eğitim düzeyine göre farklılık göstermektedir. S1caklık/Sevgi boyutu için grup varyansları homojen olmadı̆̆ından $(\mathrm{p}=0,004<0,05)$, gruplar arası farklılıkların incelenmesi aşamasında, Dunnett $C$ testi uygulanmıştır. Test sonuçları Tablo 21'de verilmiştir.

Tablo 21. Genel Tanr Algzsina İlişkin Dunnett C Testi Sonuçlar

\begin{tabular}{|c|c|c|c|}
\hline & & Ortalama Farkı & Standart Hata \\
\hline \multirow{3}{*}{ Okuryazar/değil } & İlköğretim &,- 064 & 077 \\
\hline & Lise &,$- 302^{*}$ &, 100 \\
\hline & Üniversite &,- 085 & 082 \\
\hline \multirow{3}{*}{ İlköğretim } & Okuryazar/değil &, 064 & 077 \\
\hline & Lise &,$- 238^{*}$ & 079 \\
\hline & Üniversite &,- 020 &, 055 \\
\hline \multirow{3}{*}{ Lise } & Okuryazar/değil & ,302* & ,100 \\
\hline & İlköğretim & ,238* & 079 \\
\hline & Üniversite &, 217 & 084 \\
\hline \multirow{3}{*}{ Üniversite } & Okuryazar/değil & 085 & 082 \\
\hline & İlköğretim &, 020 & 055 \\
\hline & Lise &,- 217 & 084 \\
\hline
\end{tabular}

Tablo 21 incelendiğinde, analiz sonucuna göre, 36-45 ve 46-55 yaş grupları arasında anlamlı bir farklılık görülmektedir. Gruplara ait tanımlayıcı istatistikler Tablo 22'de gösterilmiştir.

Tablo 22. Sucaklık/Sevgi Bakımından Gruplara Ait Tanmlayuc Istatistikler

\begin{tabular}{lccc}
\hline Boyutlar & $\mathbf{N}$ & $\overline{\boldsymbol{x}}$ & $\mathbf{S}$ \\
\hline Okuryazar/değil & 10 & 1,437 &, 222 \\
İlköğretim & 122 & 1,502 &, 369 \\
Lise & 52 & 1,740 &, 521 \\
Üniversite & 11 & 1,522 &, 145 \\
\hline
\end{tabular}

Tablo 22 incelendiğinde, lise mezunlarının S1caklık/Sevgi düzeyi okuryazar olan/olmayan ve ilköğretim mezunu katılımcılara göre oldukça yüksektir. Araştırmanın üçüncü alt amaçlarından üçüncüsü olan özel gereksinimli çocuğa sahip annelerin çocuğunu kabul-ret düzeylerinin annelerin iş durumuna göre farklılaşıp farklılaşmadığına dair bulgular Tablo 23’te verilmiştir.

Tablo 23: Özel Gereksinimli Cocuğa Sahip Annelerin Cocuğunu Kabul-Ret Düzeylerinin Annelerin İs Durumuna Göre Farkhlaşıp Farkhlasmadiğına Dair Yapılan Bağımsız. Örneklem T-Testi Sonuçar

\begin{tabular}{|c|c|c|c|c|c|c|}
\hline & & \multicolumn{2}{|c|}{$\begin{array}{c}\text { Varyans Eşitliği İçin } \\
\text { Levene Testi }\end{array}$} & \multicolumn{3}{|c|}{ t-testi sonuçları } \\
\hline & & $\mathbf{F}$ & Sig. & $\mathrm{t}$ & df & $\mathrm{p}$ \\
\hline \multirow{2}{*}{ Sicakl1k/Sevgi } & Eşit varyans & 10,649 & 001 & 2,609 & 182 &, 010 \\
\hline & Eşit olamayan varyans & & & 2,363 & 100,884 &, 020 \\
\hline \multirow{2}{*}{ Düşmanlık/Saldırganlık } & Eşit varyans & 1,848 & , 176 &,- 314 & 182 & ,754 \\
\hline & Eşit olamayan varyans & & &,- 300 & 117,837 & ,765 \\
\hline \multirow{2}{*}{ Kayıtsılılk/İhmal } & Eşit varyans & ,430 & ,513 &,- 506 & 182 & ,614 \\
\hline & Eşit olamayan varyans & & &,- 541 & 162,099 &, 590 \\
\hline \multirow{2}{*}{ Ayrı̧̧mamış Reddetme } & Eşit varyans & 1,142 & 287 & ,689 & 182 & ,492 \\
\hline & Eșit olamayan varyans & & & 694 & 137,482 & ,489 \\
\hline \multirow{2}{*}{ Kontrol } & Eşit varyans & 012 & ,913 & 107 & 182 & 915 \\
\hline & Eşit olamayan varyans & & & 110 & 142,947 & ,913 \\
\hline \multirow{2}{*}{ Genel Kabul-Red Düzeyi } & Eşit varyans & ,480 &, 489 & 915 & 182 &, 362 \\
\hline & Eșit olamayan varyans & & & 906 & 130,824 &, 367 \\
\hline
\end{tabular}


Tablo 23 incelendiğinde, yapılan bağımsız örneklem t-testi sonuçlarına göre, Sıcaklık/Sevgi alt boyutu için $\mathrm{p}<0,05$ olup anlamlı düzeyde farklılık bulunmuştur. Düşmanlık/Saldırganlık, Kayıtsızlık/İhmal, Ayrışmamış Reddetme, Kontrol ve Genel Kabul-Red Düzeyi için p $>0,05$ olup anlamlı bir farklılık bulunamamıştır. Özel gereksinimli çocuğa sahip annelerin Sıcaklık/Sevgi düzeyleri, annelerin iş durumuna göre anlamlı düzeyde farklılaşmaktadır. Gruplara ait tanımlayıcı istatistikler Tablo 24'de verilmiştir.

Tablo 24. Sucaklık/Sevgi Bakımindan Gruplara Ait Tanmlaynci İstatistikler

\begin{tabular}{lccc}
\hline Boyutlar & $\mathbf{N}$ & $\overline{\boldsymbol{x}}$ & $\mathbf{S}$ \\
\hline Çalışyor & 66 & 1,679 &, 506 \\
Çalışmiyor & 118 & 1,513 &, 352 \\
\hline
\end{tabular}

Tablo 24 incelendiğinde, çalışan annelerin Sıcaklık/Sevgi düzeylerinin çalışmayanlara göre daha yüksek olduğu görülmektedir. Araştırmanın dördüncü alt amaçlarından üçüncüsü olan özel gereksinimli çocuğa sahip annelerin çocuğunu kabul-ret düzeylerinin annelerin gelir durumuna göre farklılaşıp farklılaşmadığına dair bulgular Tablo 25 'te verilmiştir.

Tablo 25. Özеl Gereksinimli Cocuğa Sabip Annelerin Çocuğunu Kabul-Ret Düzeylerinin Annelerin Aylhk Gelirine Göre Farkhlisašp Farkhlaşmadiğina Dair Yapulan Tek Yönlü Varyans Analizi Sonuçlar

\begin{tabular}{|c|c|c|c|c|c|c|}
\hline & & KT & sd & KO & $\mathbf{F}$ & $\mathrm{p}$ \\
\hline \multirow{3}{*}{ S1cakl1k/Sevgi } & Gruplar aras &, 836 & 3 & ,279 & 1,640 & 181 \\
\hline & Gruplar içi & 32,457 & 191 & ,170 & & \\
\hline & Toplam & 33,293 & 194 & & & \\
\hline \multirow{3}{*}{ Düşmanlık/Saldırganlık } & Gruplar aras1 & ,912 & 3 & ,304 & 820 & 485 \\
\hline & Gruplar içi & 70,889 & 191 & ,371 & & \\
\hline & Toplam & 71,802 & 194 & & & \\
\hline \multirow{3}{*}{ Kayıtsılılk/İhmal } & Gruplar aras1 & ,853 & 3 & ,284 & 1,051 & ,371 \\
\hline & Gruplar içi & 51,661 & 191 & ,270 & & \\
\hline & Toplam & 52,514 & 194 & & & \\
\hline \multirow{3}{*}{ Ayrışmamış Reddetme } & Gruplar aras1 & ,102 & 3 & ,034 & ,175 & 913 \\
\hline & Gruplar içi & 37,140 & 191 & ,194 & & \\
\hline & Toplam & 37,242 & 194 & & & \\
\hline \multirow{3}{*}{ Kontrol } & Gruplar aras1 & 1,062 & 3 & ,354 & 1,319 & 269 \\
\hline & Gruplar içi & 51,245 & 191 & ,268 & & \\
\hline & Toplam & 52,307 & 194 & & & \\
\hline \multirow{3}{*}{ Genel Kabul-Red Düzeyi } & Gruplar aras1 & ,119 & 3 & ,040 & 682 &, 564 \\
\hline & Gruplar içi & 11,103 & 191 & ,058 & & \\
\hline & Toplam & 11,222 & 194 & & & \\
\hline
\end{tabular}

Tablo 25 incelendiğinde, yapilan tek yönlü varyans analizi sonucuna göre, tüm boyutlar için $p>0,05$ düzeyde olduğundan anlamlı bir farklılık bulunamamıştır. Özel gereksinimli çocuğa sahip annelerin Ebeveyn Kabul-Ret düzeyleri, ailenin gelir durumuna göre farklılık göstermemektedir. Araştırmanın alt amaçlarından beşincisi olan özel gereksinimli çocuğa sahip annelerin tanrı algıları ile umutsuzluk düzeyleri arasındaki ilişkiye dair bulgular Tablo 26'da verişmiştir.

Tablo 26. Değğskenler Arası Ilişkiyi Açılamaya Yönelik Korelasyon Analizi Sonuçlar

\begin{tabular}{llc}
\hline & & Tanr1 Alg1s1 \\
\hline \multirow{3}{*}{ Umutsuzluk } & Pearson Correlation &,$- 218^{* *}$ \\
& $\mathrm{p}$ &, 002 \\
& $\mathrm{~N}$ & 195 \\
\hline
\end{tabular}

**0,01 düzeyinde önemli iliş̧ki

Tablo 26 incelendiğinde, yapılan korelasyon analizi sonucunda, anlamlı düzeyde bir ilişki belirlenmiş olup özel gereksinimli çocuğa sahip annelerin umutsuzluk düzeyi ve tanrı algısı düzeyleri arasında 0,01 düzeyinde önemli bir ilişki bulunmuştur. İki değişken arasındaki korelasyonun negatif yönlü olması, önemli bir araştırma bulgusu olarak değerlendirilmektedir. Bu bulgu, katılımcıların tanrı alg1sı yükseldikçe 
umutsuzluğunun azaldığını göstermektedir. Tanrı algısı alt boyutları ile umutsuzluk arasındaki ilişkiyi açıklamak üzere yapılan regresyon analizi sonuçları Tablo 27'de verilmiştir.

Tablo 27. Tanr Algısı Alt Boyutlar İle Umutsụ̊luk Arasındaki İlişkiyi Açıklamak Üzere Yapılan Regresyon Analizi Sonuclar

\begin{tabular}{lccccc}
\hline & $(\boldsymbol{\beta})$ & St.Hata & $(\mathbf{t})$ & $\mathbf{p}$ & $\mathbf{R}^{2}$ \\
\hline Sevgi Yönelimli & $-0,035$ & 0,013 & $-2,637$ & 0,009 & 0,049 \\
Korku Yönelimli & $-0,038$ & 0,016 & $-2,438$ & 0,016 & \\
\hline
\end{tabular}

Bağımlı Değişken: Umutsuzluk

Tablo 27 incelendiğinde, sevgi ve korku yönelimli tanr1 algılarının umutsuzluğu olumsuz yönde etkilediği görülmektedir. Bununla birlikte umutsuzluğu etkileme boyutunda $(\beta)$ düşük bir farkla da olsa korku yönelimli tanrı algısının sevgi yönelimli tanrı algısından daha fazla etkilemektedir. Sevgi ve korku yönelimli tanrı algıları, umutsuzluk değişkeninin \%4’ünü açıklamaktadır. Bu bulgu umutsuzluk değişkenini kalan kısmının bu araştırma dışındaki başka değişkenlerden etkilendiğini göstermektedir. Araştırmanın alt amaçlarından altıncısı olan özel gereksinimli çocuğa sahip annelerin umutsuzluk düzeyi ile çocuğunu kabul-ret arasındaki ilişkiye dair bulgular Tablo 28'de verilmiştir.

Tablo 28. Değiş̧kenler Arasi Ilişkeiyi Açılamaya Yönelik Korelasyon Analiz̧i Sonuçlan

\begin{tabular}{lll}
\hline & & Kabul-Ret \\
\hline \multirow{2}{*}{ Umutsuzluk } & Pearson Correlation &, $208^{* *}$ \\
& $\mathrm{p}$ &, 004 \\
& $\mathrm{~N}$ & 195 \\
\hline
\end{tabular}

${ }^{* *} 0,01$ düzeyinde önemli ilişki

Tablo 28 incelendiğinde, yapılan korelasyon analizi sonucunda, anlamlı düzeyde ilişki bulunmuştur ve özel gereksinimli çocuğa sahip annelerin umutsuzluk düzeyi ve çocuğunu kabul-ret düzeyleri arasında 0,01 düzeyinde önemli ilişki bulunmuştur. İki değişken arasında pozitif yönlü bir korelasyon söz konusudur. Bu bulgu, katıllmcıların umutsuzluk düzeyi yükseldikçe ebeveyn kabul-ret düzeyinin de yükseldiğini göstermektedir. Umutsuzluk alt boyutları ile ebeveyn kabul-ret değişkeni arasındaki ilişkiyi incelemek üzere yapılan regresyon analizi sonuçları Tablo 29'da verilmiştir.

Tablo 29. Umutsu₹luk Alt Boyutlar İle Ebeveyn Kabul-Ret Değģskeni Arasindaki İliskizi Incelemek Üzrere Yapulan Regresyon Analizi Sonuclar

\begin{tabular}{lccccc}
\hline & $(\boldsymbol{\beta})$ & St.Hata & $\mathbf{( t )}$ & $\mathbf{p}$ & $\mathbf{R}^{2}$ \\
\hline Gelecekten Beklenti & 0,122 & 0,102 & 1,201 &, 231 & 0,046 \\
Motivasyon Kayb1 & 0,112 & 0,053 & 2,109 &, 036 & \\
Umut & 0,152 & 0,073 & 2,071 &, 040 & \\
\hline
\end{tabular}

Bağımlı Değişken: Ebeveyn kabul-ret

Tablo 29 incelendiğinde, gelecekten beklenti ile ebeveyn kabul-ret düzeyi arasinda $\mathrm{p}>0,05$ düzeyde olup istatistiksel olarak anlamlı bir ilişki bulunamamıştır Buna karşlık motivasyon kaybı ve umut alt boyutları, ebeveyn kabul-ret düzeyini $\mathrm{p}<0,05$ düzeyde olumlu yönde etkilerken, umut değişkenin motivasyon kaybından daha etkili olduğu söylenebilmektedir ( $\beta$ ). Bunun anlamı katılımcıların motivasyon kayb1 ve umut düzeyleri yükseldikçe ebeveyn kabul-ret düzeyleri de yükselmektedir. Umutsuzluk alt boyutları, ebeveyn kabul-ret değişkeninin \%4'ünü açıklamaktadır. Araştırmanın alt amaçlarından yedincisi olan özel gereksinimli çocuğa sahip annelerin tanrı algısı ve çocuğunu kabul-ret arasındaki ilişkiye dair bulgular Tablo 30'da verilmiştir.

Tablo 30. Değiş̧kenler Arası İlişkiyi Açılamaya Yönelik Korelasyon Analiẓi Sonuçlan

\begin{tabular}{llc}
\hline & & Kabul-Ret \\
\hline \multirow{2}{*}{ Tanr1 Alg1s1 } & Pearson Correlation &,$- 060^{* *}$ \\
& P &, 403 \\
& N & 195 \\
\hline
\end{tabular}

${ }^{*} 0,01$ Düzeyinde Önemli İliş̧ki

Tablo 30 incelendiğinde, yapılan korelasyon analizi sonucunda özel gereksinimli çocuğa sahip annelerin tanr1 algısı ve çocuğunu kabul-ret düzeyleri arasında anlamlı bir ilişki bulunamamıştır. Araştırmanın alt amaçlarında sekizincisi alt amaçlarından olan özel gereksinimli çocuğa sahip annelerin 
umutsuzluk düzeyi, tanr1 algısı ve çocuğunu kabul-ret düzeyleri arasında anlamlı düzeyde ilişkiye dair bulunan sonuç Şekil 1'de gösterilmiştir

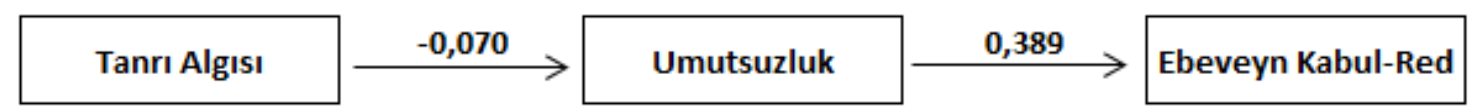

Şekil 1. Tanr algısı, umutsųluk ve kabul-ret arasindaki ilişki

Şekil 1 incelendiğinde, araştırmanın en önemli bulgularından biri olarak; tanrı algısı umutsuzluğu olumsuz etkilerken, umutsuzluk, ebeveyn kabul-ret düzeyini olumlu yönde etkilemektedir ve tanrı algisı ile ebeveyn kabul-ret arasında bir ilişki yoktur. Bu bulgulara göre, umutsuzluk değişkeninin, tanrı algisı ile ebeveyn kabul-ret değişkenleri arasında bir mediatör (1lımlaştırıc1) değişken etkisinden söz edilebilmektedir. Mediatör (Ilımlaştırııı) Değişken; Bağımsız ve bağımlı değişkenler arasında gözlemlenen bir ilişiknin gücünü ve değişkenlerle farklı ilişkisi olması sebebiyle, ortadan kaldıran veya azaltan değişken olarak tanımlanır. Mediatör (Ilımlaştırıcı) Değişken hem bağımlı değişkene hem bağımsız değişkene etki eder (Gödeş, 2019).

\section{Tartışma, Sonuç ve Öneriler}

Bu bölümde yapılan analizler sonucu elde edilen bulguların literatür de ulaşılan araştırma bulguları ile karşılaştırılmasına yer verilmiştir. Ayrıca elde edilen araştırma bulgularına dayanarak uygulamacılara ve ileri araştırmalar için araştırmacılara önerilerde bulunulmuştur.

Araştırmanın birinci alt amacı olan özel gereksinimli çocuğa sahip annelerin umutsuzluk düzeyi, Tanrı algısı ve çocuğunu kabul-ret düzeyleri, annelerin yaşlarına göre anlamlı düzeyde farklılaşıp farklılaşmadığ1 ile ilgili bulgular tartışılmıştır. Araştırma sonucuna göre, özel gereksinimli çocuğa sahip annelerin umutsuzluk düzeyleri, annelerin yaşlarına göre farklılık göstermemektedir. Eş (2013, s. 81), yaptığı çalışma da annelerin umutsuzluk düzeyinin annelerin yaş değişkeni açısından yapılan analizlerde Umutsuzluk Ölçeği’ nin geleceğe yönelik beklentileri ile umutsuzluk alt boyutlarında istatistiksel olarak anlamlı bir fark bulunmamıştır. Bu bulgu yapılan bu araştırmayı desteklemektedir. Fakat Sarpdağı (2018, s. 49) yaptı̆̆ araştırmada katılımcının yaşı ile umutsuzluk puanı arasında pozitif yönlü düşük düzeyli, anlamlı ilişki bulunmuştur, katılımcının yaşı arttıkça umutsuzluk puanı da artmaktadır. Bu araştırma sonucu yapılan araştırmayı desteklemiyor görünse de Sarpdağı’ nın araştırmasında da var olan ilişkinin düşük düzeyde çıkmış olması da dikkat çekmektedir.

Araştırmada çıkan sonuçlara bakıldığında umutsuzluk düzeyinin annelerin yaşlarına göre anlamlı düzeyde farklılık göstermemesinin sebebi umutsuzluklarını etkileyen başka sebeplerin daha yoğunlukta olması ya da annelerin sosyal yaşam algıları, toplum kuralları, kültürel etkiler aynı bölgede yaşamaları sebebiyle benzer olabileceği düşünüldügüu için, geleceğe dair umutsuzluk, isyan ve karamsarllk bireyin inanç ve yaşam tarzına aykırı olabileceği ihtimali sebebiyle yaşa göre farklılık göstermeyebilir. Bir diğer sebep olarak yaş dağılımına bakıldığında, \%51'lik kısmı oluşturan grup 36-45 yaş grubundadır. Örneklemin yarısını oluşturduğu görüldüğünden bu grup sonuç üzerinde en yüksek etkiye sahiptir. Bu sebeple çıkan sonucun bu gruptan etkilendiği söylenebilir. Bir diğer faktör, çocukların yetersizlik tür ve derecesinin belirsizliği çıkan sonucu etkileyebilir.

Özel gereksinimli çocuğa sahip annelerin tanrı algılamaları, annelerin yaşlarına göre anlamlı bir farklılık göstermemektedir. Koç (2011, s. 82), araştırmasında katılımcıların Tanrı tasavvurları ve demografik değişkenlerine ilişkin yapılan analizlerde yaşa göre herhangi bir temel etki, etkileşim etkisi ya da farklılaşma görülmemiştir. Güler (2007a, s. 139), bir araştırmasında yaş dönemlerine göre bireylerin Tanrı algılarının farklılık göstermediğini bulmuştur. Noffke ve McFadden (2001 Akt: Koç, 2011, s. 82) Tanrı algısı ile çalışmalarında yaşlar arası farklılık saptanmamıştır. Bu çalışmalar araştırmayı destekler niteliktedir. Farklı bir araştırma sonucuna göre Güngördü'nün (2001, s. 139) 17-36 yaşlar arasındaki öğrenciler üzerinde yaptı̆̆ çalışmasında düşük yaş gruplarının yüksek yaş guruplarına göre daha olumsuz bir Tanrı algısına sahip oldukları sonucuna ulaşmıştır. Yine benzer şekilde Alçelik (2013, s. 76), çalışmasında yaş grupları ve Tanrı tasavvuru alt boyutları arasında anlamlı bir ilişki bulunamamıştır. Fakat ortalamalara bakıldığında Koruyup/ Gözeten, Teslim Olunan, Yetkin ve Seven alt boyutlarında yaş ilerledikçe katılımcıların puanlarının yükseldiği görülmektedir. Araştırmada tanrı algısının yaşa göre farklılaşmamasının sebebi bu durum Allah kavramının kapsayıcilığı ve yaşla birlikte önemli ölçüde değişen bir konu olmaması olarak yorumlanabilir. Annelerin yaş grubu 25 yaş üstü olarak belirlendiği için Tanrı kavramının zihinde 
oturmuş olması ve yaşa göre değişiklik göstermemesi beklenen bir durumdur. Özel gereksinimli çocuğa sahip annelerin Sıcaklık/Sevgi ve Ayrışmamış Reddetme düzeyleri, annelerin yaşlarına göre farklılık göstermektedir. Analiz sonucuna göre, 36-45 ve 46-55 yaş grupları arasında anlamlı bir farklılık görülmektedir. 46-55 yaş grubundaki annelerin Sıcaklık/Sevgi düzeyinin diğer gruplara göre daha yüksek olduğu görülmektedir. Ayrışmamış reddetme boyutunda analiz sonucuna göre, $36-45$ ve $46-55$ yaş grupları arasında anlamlı bir farklilık görülmektedir. 36-45yaş grubundaki annelerin Ayrışmamış Reddetme düzeyinin diğer gruplara göre daha yüksek olduğu söylenebilir.

Failla ve Jones (1991 Akt: Dere, 2009, s. 66), farklı bir ilişki bularak ilerleyen yaşlarda kabullenmenin azalmasıyla ilgili bulduğu sonuçlara göre engelli çocukların yaşlı annelerinin, genç annelere göre daha stresli olduğu; çünkü onlanın, daha büyük aile ile uğraşıp, daha çok ilişkide bulunmasının buna etken olduğunu düşünmektedir. Bazı araştırma sonuçları, annenin yaş faktörünün anne kabulü ile ilişkili bulunmuştur (Campo ve Rohner 1992; Schumacher vd., 1999 Akt: Erkan ve Toran, 2004, s. 94) annenin yaşı ile kabulret davranışı arasında bir ilişkinin olduğunu ve annenin yaşının ilerlemesinin çocuğa karşı davranışlarını da olumsuz yönde etkilediği belirtmiştir. Araştırmalarda anne yaşının çocuğa gösterilen kabul ve ret üzerinde önemli düzeyde etkili olduğunu saptamıştır. Anne yaşı ile çocuğunu kabul-reddi arasında farklı yönde ilişki kuran çalışmalara bakıldığında anne yaşı ile ebeveyn kabul-reddi arasında ilişki bulunmadığını söyleyen Muştu Eren (2018, s. 38), çalışmasında sıcaklık-şefkat, düşmanlık, ihmal, ret, kontrol ve ebeveyn kabul ret ölçeklerinin puanları ile annelerin yaşları arasında istatistiksel olarak ilişki olmadığı görülmüştür. Dere (2009, s. 66) tarafindan yapılan çalışmada otizm tanılı çocuk sahibi annelerin yaşı ile kabul ret düzeyi arasında anlamlı bir ilişki olmadığı sonucuna varılmıştır. Tezel-Şahin ve Özyürek (2008, s. 409), 5-6 yaş aralığında bulunan çocuklara sahip annelerin tutumlarını incelemiş ve anne tutumlarının anne yaşı değişkeni açısından anlamlı ölçüde farklı olmadığı sonucunu elde etmişlerdir. Arslan (2010, s. 58), ebeveyn kabul veya reddinin, bireylerin kişilik özelliklerine etkisini ortaya koymak amacıyla yaptığı araştırmada ebeveyn kabul ret ölçeği puanlarının yaş grupları açısından anlamlı bir farklılık göstermediğini ortaya koydu. $\mathrm{Bu}$ araştırmada yaşa göre bulunan farklılık, yaş düzeyi arttıkça (46 ve üzeri) sıcaklık ve sevgi puanının artması yaşa ve zamana göre çocuğa alışma, çocuğun ihtiyaçlarını karşılayabilmeyle ilgili duyulan tatmin, bilinçlenme durumları göz önüne alındığında yaş ilerledikçe aileler sadece sevgi ve ilgi üzerine eğilmiş olabilirler. Bireyler yaşlandıkça, dünyada çocuklarıyla geçirdikleri zamanın azaldığının farkındalığ ile ya da geçmişte (genç yaşlarda) çocuğa gösterilemeyen ilginin sevginin telafisi için yaşın ilerlemesiyle sevgi ve sıcaklık göstermeye eğilim başlayabilir. Ayrışmamış reddetme puanın yalnızca 36-45 yaş grubunda yüksek olması, anlamlı bulunmamıştır.

Araşıırmanın ikinci alt amacı olan özel gereksinimli çocuğa sahip annelerin umutsuzluk düzeyi, Tanrı algisı ve çocuğunu kabul-ret düzeyleri, annelerin eğitim düzeylerine göre anlamlı düzeyde farklılaşıp farklılaşmadığı ile ilgili bulgular tartışılmıştır. Araştırma sonucuna göre, özel gereksinimli çocuğa sahip annelerin genel umutsuzluk düzeyleri, annelerin eğitim düzeylerine göre farkll1lk göstermektedir. Okuryazar olan/olmayan katılımcılar ile üniversite mezunları arasında anlamlı bir farklılık görülmektedir. Okuryazar olan/olmayan katılımclların genel umutsuzluk düzeyinin üniversite mezunları ve diğer gruplardan daha düşük olduğu görülmektedir.

Sarpdağ1 (2018, s. 47) yaptı̆̆ çalışmada; umutsuzluk düzeyi yüksek olan annelerin eğitim düzeylerinin düşük olduğu sonucunu bulmuştur. Çengelçi (2009, s. 19) eğitim düzeyi düşük olan bireylerin umutsuzluk düzeylerinin daha yüksek olduğunu bulduğu çalş̧masını otizm ve down sendrom'lu çocuğa sahip anneler üzerinde yapmıştır. Akandere, Acar ve Baştuğ, (2009, s. 27) ilkokul mezunu olan annelerin geleceğe dair duygu ve beklentilere ilişkin puanları üniversite mezunu olan annelerin puanlarından anlamlı derecede yüksek bulunmuştur. Literatürdeki araştırma sonuçları bu çalışmayı desteklememektedir. Çalışmada eğitim düzeyi düşük annelerin umutsuzluk düzeyinin düşük olması, çocuğun hangi tür ve derecede yetersizlik yaşadığına bağlı olarak bir sonuç çıkmış olabilir ya da annelerin geleceğe dair kendileri ve çocukları ile ilgili yüksek beklenti içine girmemeleriyle açılanabilir.

Özel gereksinimli çocuğa sahip annelerin genel tanrı algilamaları, annelerin eğitim düzeyine göre farklılık göstermektedir. Analiz sonucuna göre, ilköğretim ve lise mezunları arasında anlamlı bir farklılık görülmektedir. İlköğretim mezunlarının tanrı algısı lise mezunlarında anlamlı bir şekilde daha yüksektir. Genel tanrı algısı en düşük olan grup lise mezunlarıdır. Çınar (2015, s. 63) yaptığı çalısmada elde edilen bulgulara göre ise eğitim düzeyi arttıkça Tanrı'ya güvenli bağlanma puanlarının azaldığı görülmektedir. Alçelik (2013, s. 110) bireylerin öğrenim durumuna bakıldığında müdahale ve kontrol eden Tanrı tasavvuru alt boyutunda okuryazar olmayan bireyler ile okuryazar ve lise mezunu olan bireyler ile anlamlı bir farklilik olduğu görülmektedir. Murphy vd. (2000), yaptığı klinik çalışmada eğitim seviyesi ile dini inançların ters 
yönde ilişkili olduğunu bulmuştur. Hood, Hill ve Spilka (2009) ise yüksek eğitim seviyesinin manevi tecrübeler ve dini başa çıkmalar ile doğrudan ilişkili olduğunu belirtmişlerdir.

Eğitim ile Tanrı algısı ve dini başa çıkma arasındaki ilişki hakkında farklı sonuçlar veren çalışmalar mevcuttur. Çalışmaların yapıldığı, ülke, kültür ve inanılan din gibi etkenlerin farklılığı sonuçların farklılaşmasina sebep olabilmektedir. Akyüz (2010, s. 72) demografik değişkenlere göre yaptı̆̆1 çalışmasında öğrenim durumu ile Tanrı tasavvuru arasında anlamlı bir farklılık tespit edilememiştir. Aydın (2011, s. 104) Türk Müslüman katılımcılara yaptığı çalışmada ise Tanrı algısıyla eğitim düzeyi arasında bir ilişki bulunmamıştır. Mehmedoğlu (2011, s. 222) da yaptığı çalışmada öğrenim düzeyi Allah tasavvurunu kısmen etkilemekte olduğu, farklı grupların pozitif ve negatif tasavvurları arasında anlamlı farklılaşmaların bulunduğu sonucuna ulaşmıştır.

Lise ve lisans düzeyinde eğitim almış olanların ilköğretim düzeyinde eğitim alanlara göre daha pozitif Tanrı algısına sahip oldukları gözlemlenmiş olup çalışmayı desteklemeyen bir araştırma sonucudur. Araştırmada ilköğretim mezunlarının Tanrı algısı lise mezunlarında anlamlı bir şekilde daha yüksektir. Genel Tanrı algısı en düşük olan grup lise mezunlarıdır sonucu anlamlı bulunmamışır. Sonuca göre bu farklılığın sebebi çalısmanın yapıldığı kültür, toplumsal etki, dini inanç gibi faktörlerin sonuçları farklılaştırdığı düşünülebilir. Eğitim düzeyi ilköğretim düzeyinde kalan annelerin Tanr1 alg1sı daha gelenekselci yapıda olduğu düşünülürse Tanrı algısının yüksek çıkması anlaşılabilir bir durumdur.

Özel gereksinimli çocuğa sahip annelerin Sıcaklı/Sevgi düzeyleri, annelerin eğitim düzeyine göre farklılık göstermektedir. Analiz sonucuna göre, 36-45 ve 46-55 yaş grupları arasında anlamlı bir farklılık görülmektedir. Lise mezunlarının Sıcaklık/Sevgi düzeyi okuryazar olan/olmayan ve ilköğretim mezunu katılımcılara göre oldukça yüksektir. Erkan ve Toran (2004, s. 94) tarafindan yapılan çalışmada, annelerin eğitim düzeyi arttıkça, çocuklarını kabul davranışlarının arttığı, eğitim düzeyi düştükçe reddedici davranışta artış olduğu bulunmuştur. Yamaç (2011, s. 70) tarafindan yapılan çalışmada zihin engelli çocuğu kabul ret düzeyinde, annelerin eğitim düzeyinin önemli bir değişken olduğu görülmektedir. Pektaş ve Özgür (2005, s. 25) tarafindan ilköğretim 3. sınıf öğrencilerinin anneleri ile olan ilişkilerini etkileyen etmenleri belirlemek amacıyla yapılan araştırmada ortaya çıkan sonuca göre Aile Kabul-Red Ölçeği genel toplam puan ortalaması açısından eğitim düzeyi düşük olan annelerin çocuklarını reddi, eğitim düzeyi yüksek olan annelere kıyasla daha yüksek bulunmuştur.

Farklı bulgulara sahip çalışmalarda Delitay (2009, s. 14) engelli çocuk annelerinin eğitim düzeyine göre reddetme davranışlarının incelenmesi sonucunda, eğitim düzeyi yüksek annelerin daha çok reddetme davranışı sergilediği görülmüştür. Üniversite ve üzerinde eğitim düzeyine sahip olan annelerin ölçekten elde ettikleri puan ortalamalarının lise, ilköğretim ve daha altında eğitime sahip olan annelerden anlamlı düzeyde yüksek olduğu sonucuna ulaşılmıştır. Bu çalışmada farklılı̆ın bulunduğu 36-45 ve 46-55 yaş grubuna bakıldığında, eğitim düzeyi arttıkça sıcaklık sevgi puanın artığ1 görülmektedir. Lise mezunu annelerin daha düşük eğitim düzeyinde olan annelere göre bilinç ve farkındalık düzeyleri daha yüksek olduğu düşünülebilir. Bu durumda çocuğa sevgi ve sıcaklık göstermenin çocuğun gelissimini olumlu yönde etkileyeceği, sevgiyle büyüyen çocuğun daha başarllı ve dengeli birey olabileceğine dair bilinç bu sonucu açıklayabilir.

Araştırmanın üçüncü alt amacı olan özel gereksinimli çocuğa sahip annelerin umutsuzluk düzeyi, Tanrı algisı ve çocuğunu kabul-ret düzeyleri, annelerin iş durumuna göre anlamlı düzeyde farklılaşıp farklılaşmadığı ile ilgili bulgular tartışılmıştır. Özel gereksinimli çocuğa sahip annelerin Umut ve Genel Umutsuzluk düzeyleri, annelerin iş durumuna göre anlamlı düzeyde farklılaşmaktadır. Çalışan annelerin umut alt boyutu ve genel umutsuzluk düzeylerinin çalışmayanlara göre daha yüksek olduğu görülmektedir. Bazı çalıssmalarda araştırmayı desteklemeyen bulgular söz konusudur. Türkoğlu (2001) çalışmayan annelerin çalışan annelere göre kaygı düzeylerinin daha yüksek olduğunu bulduğu çalışmasını zihinsel engelli çocukların anne-baba ve kardeşlerini üzerinde yapmıştır. Araştırmada çalışan annelerin umutsuzluk düzeylerinin çalışmayanlara göre yüksek olması, yoğun iş tempoları sebebiyle kendilerine sosyal zaman ayıramamaları, çocuklarılla kaliteli vakit geçirecek firsat bulamamaları, sosyal rollerinden fedakârlık etmek durumunda kalmaları ve bunun çalşma yaşamı boyunca sürecek olması annenin umutsuzluk düzeyini artırabilir.

Bu araştırmada özel gereksinimli çocuğa sahip annelerin Sevgi Yönelimli ve Genel Tanrı Algısı, annelerin iş durumuna göre anlamlı düzeyde farklılaşmaktadır. Çalışmayan annelerin Sevgi Yönelimli ve Genel Tanrı algısının çalışanlara göre daha yüksek olduğu görülmektedir. Farklı yönde bulgulara sahip 
çalışması olan Alçelik (2013, s. 81), çalışmayanlar çalışanlara göre Tanrı'yı daha fazla cezalandıran olarak alg1lamakta olup bu farkın anlamlı olduğu görülmektedir. Çalışma durumunu diğer alt boyutlar arasında anlamlı farklılıklar tespit edilememiştir. Fakat çalışmayan bireylerin merhametli, koruyup/gözeten, yakın/içkin, müdahale/kontrol eden, seven, ibadet ve inanç puanlarının çalışan bireylere nazaran daha yüksek olduğu görülmektedir. Mehmedoğlu (2011, s. 219) tarafindan yapılan bir araştırmaya göre, bireylerin çalışıp çalışmama durumu ve sosyo-ekonomik düzey Allah tasavvuru üzerinde etkili bir faktör değildir. Farklı sosyo-ekonomik düzeyde bulunan grupların tasavvurları arasında anlamlı bir farklılık görülmemiştir. Her ne kadar orta sosyo-ekonomik düzeyde bulunanlar, Allah tasavvurunun hem pozitif hem de negatif boyutlarında yüksek ve düşük sosyo-ekonomik düzeyde bulunanlardan daha olumlu tutumlara sahip gibi gözüküyorsa da anlamlı bir farklılaşma bulunmamıştır. Çalışma sonucuna göre bulunan, çalışan annelerin, Sevgi yönelimli ve Genel Tanrı algıları, çalışmayan annelere göre daha düşük olmasının sebebi olarak, çalışma yoğunluğu, yaşam şartlarının zorluğu ve çocuklarına yeterli zaman ayıramamaları annelerin Tanrı'nın kendilerine zorlayıcı davrandığı, omuzlarına gereğinden fazla yük verdiği, önemsenmediği ve bu sebeple zorluklarla baş etmesi gerektiği algisı uyandırabilir. Çalışmayan annelerin genel tanrı algisının yüksek olması ise Tanrı'ya ve dinsel kavramlar olan "kadere inanma, razı gelme" Tanr1 katında sevilen davranışlar olduğu için, Tanrı'nın kendilerini sevdiğini ve bir gün Tanrı tarafindan ödüllendirileceklerini düşünmelerine sebep olabilir.

Özel gereksinimli çocuğa sahip annelerin Sıcaklık/Sevgi düzeyleri, annelerin iş durumuna göre anlamlı düzeyde farklılaşmaktadır. Çalışan annelerin Sıcaklık/Sevgi düzeylerinin çalışmayanlara göre daha yüksek olduğu görülmektedir. Literatürde farklı bulgulara sahip çalışmalar mevcuttur. Bailey ve Simeonsson (1988, s. 220) annenin iş yüküne ek olarak, engelli çocuğun anneye bağımlı olması ve günün (çalışma saatlerinin dışındaki zamanların) hemen hemen tamamında annenin yanında olması annenin psikolojik sağlığını olumsuz etkileyebilir. Bunun sonucunda da çalsşan annelerin diğer gruplardaki annelere oranla çocuklarına yönelik daha az sevgi gösterdikleri; saldırganlık ve ihmâl davranışlarının da daha fazla olduğu söylenebilir. Benzer bir bulguyu ifade eden Aktaş (1994, s. 11), çalışan annelerin çalş̧mayan annelere göre çocuklarının fiziksel bakımında daha az zaman harcamalarının, bu ailelerde anne-çocuk ilişkisinin daha fazla yıpranmasına neden olduğunu belirtmiştir. Çocuğun fiziksel açıdan ihtiyaçlarının karşılanmaması zaten ihmal olarak değerlendirilmekte ve söz konusu alt ölçekten ve ölçeğin genelinden yüksek puan alınması sonucunu yaratmaktadır. Yakmaz ve Basılgan (2012, s. 122), bu çalışmada elde edilen bulgulara göre annesi çalışan ya da çalışmayan çocukların EKRÖ sıcaklık/sevgi, saldırganlık/kin, ilgisizlik/ihmal, ayrışmamış reddetme alt boyutları ve toplam EKRÖ'deki puanları arasında anlamlı düzeyde bir farklılık bulunmamaktadır. Diğer bir ifadeyle annesi çalışan çocukların ve annesi çalışmayan çocukların ebeveyn kabul-red düzeyleri benzerdir. Kejerfors (2007 Akt: Yakmaz ve Basılgan, 2012, s. 117) EKRÖ’ni kullanarak yaptığı çalışmada çocukların ebeveynlerin mesleki durumuna ya da çalışan ya da çalışmayan ebeveynlere yönelik kabul-red algılamasında önemli bir farklılık olmadığını ortaya çıkardı. Bu çalışmada çalışan annelerin çocuğuna karşı Sıcaklık-.sevgi puanı çalışmayan annelere göre daha yüksek olmasının sebebi, annelerin iş yoğunlukları ve uzun çalışma süreleri sebebiyle çocuklarılyla doyurucu düzeyde vakit geçirememeleri onların çocuklarına karşı daha sevgi dolu ve sıcak davranışlar sergileyerek kendilerini eksik hissettikleri durumları telafi etmeye çalışmaları bu durumu açıklayabilir.

Araştırmanın dördüncü alt amacı olan özel gereksinimli çocuğa sahip annelerin umutsuzluk düzeyi, Tanr1 algısı ve çocuğunu kabul-ret düzeyleri, ailenin aylık gelirine göre anlamlı düzeyde farklılaşıp farklılaşmadığı ile ilgili bulgular tartışılmışır. Özel gereksinimli çocuğa sahip annelerin Geleceğe yönelik duygu/beklenti, motivasyon kaybı, umut ve genel umutsuzluk düzeyleri, ailenin gelir durumuna göre farklılık göstermemektedir. Şimşek' in $(2015$, s. 33) otistik çocukların anneleri üzerine yaptığ çalışmada ve Yıldız'ın (2007 Akt: Sarpdağı, 2014, s. 44) ise kanserli hastaya bakım veren aile üyeleri üzerinde yaptı̆̆1 çalışmada geliri az olarak ifade eden bireylerin umutsuzluk düzeyinin daha fazla olduğunu bulmuştur. Akarsu (2014, s. 57) tarafindan zihinsel engelli çocuğu olan anne babalar üzerinde yaptığı araştırmada; gelir düzeyinin artmasıyla yaşam doyumunun da arttı̆g sonucunu bulmuştur. Bu çalışmada ise annenin gelir düzeyinin umutsuzlukları üzerinde herhangi bir etkisinin olmaması sonucuna ulaşılmasının sebebi olarak, ailenin çocuğuyla ve gelecekle ilgili maddi yükümlülük getiren planlarının olmaması, ya da yaşadıkları coğrafyada kırsal alanda, ihtiyaçların karşılanması yaşamın sürdürülmesi için gelir düzeyinin yüksek olmasının gereklilik olmadığı düşünülebilir.

Özel gereksinimli çocuğa sahip annelerin Tanrı algılamaları, ailenin gelir durumuna göre farklılık göstermemektedir. Uysal, Batan, Baş, Zafer (2014, s. 229) tarafindan yapılan bir araştırmada ailelerin gelir düzeyleri ile Tanrı algıları arasında anlamlı bir fark olmadığı gözlenmiştir. Mehmedoğlu (2011, s. 219) 
tarafindan yapılan bir araştırmaya göre de sosyo-ekonomik düzey Allah tasavvuru üzerinde etkili bir faktör değildir. Farklı sosyo-ekonomik düzeyde bulunan grupların tasavvurları arasında anlamlı bir farklılık görülmemiştir. Her ne kadar orta sosyo-ekonomik düzeyde bulunanlar, Allah tasavvurunun hem pozitif hem de negatif boyutlarında yüksek ve düşük sosyo-ekonomik düzeyde bulunanlardan daha olumlu tutumlara sahip gibi gözüküyorsa da anlamlı bir farklılaşma bulunmamıştır. Karşıt sonuçlar bulan çalışmalara bakıldığında Ceylan (2018, s. 103) çalışmasında maddi durum ile psikolojik iyi oluş arasında pozitif ilişki görülmüştür. Ayrıca analizlere göre, maddi durum ile korku yönelimli Tanrı algısı arasında pozitif ilişki görülürken; olumsuz dini başa çıkma ile maddi durum arasında negatif ilişki bulunmuştur. $\mathrm{Bu}$ durumda bireylerde maddi durum arttıça korku yönelimli Tanrı algısı artarken; olumsuz dini başa çıkmayı daha az kullandığı görülmüştür. Bireylerin maddi durumun artması ile gerçekleşen psikolojik iyi oluş sayesinde birey olumsuz dini başa çıkma mekanizmalarını daha az kullanması beklenilebilir bir sonuçtur. Fakat Tanrı algılarının sevgi yönelimli Tanrı'dan korku yönelimli Tanrı algısına evrilmesi dikkat çekicidir. Maddi anlamda rahata eren birey Tanr1 tarafindan cezalandırıldığını düşünmesi hipotezimizle uyuşmamaktadır. Bu çalışmayı destekler nitelikte olan araştırma sonucunda da belirtildiği gibi, dini inanışa göre, parasal eksiklik ya da fazlalık Tanrı inancını etkileyecek bir sebep olarak görülmeyebilir. Bireyler Tanrı'ya koşulsuz bağlıdırlar ve onun tarafından kendilerine verilen hayatı kabul ederek ve kader inancıyla hareket ederek yaşıyor olmaları, gelir düzeylerinin fazla ya da az olması annelerin de Tanrı algısını etkilemediği söylenebilir.

Özel gereksinimli çocuğa sahip annelerin Ebeveyn Kabul-Ret düzeyleri, ailenin gelir durumuna göre farkll11k göstermemektedir. Destekleyici bir bulgu olan Dere (2009, s. 57) tarafindan otizmli çocukların anneleri üzerinde yaptı̆̆ çalışmaya göre gelir düzeyi ile kabul ret düzeyi arasında anlamlı bir fark olmadığ1 sonucu çıkmıstır. Ailede gelir kaynağı baba olabileceği durumunu göz önünde bulundurarak yapılan bir çalışmanın bulgusunda Tekin (2017, s. 145), tarafından gerçekleştirilen çalışmada da babanın otizmli çocuğunu kabul-ret düzeyi ile gelir düzeyi arasında anlamlı bir fark bulunamamıştır. Kaplan (2005, s. 117) annelerin çocuklarına karşı olan kabul ret davranışlarının ailenin aylık gelir düzeyine göre istatistiksel olarak anlamlı düzeyde bir farklılık olmadığı tespit edilmiştir. Farklı bir çalışmada; Muştu Eren $(2018$, s. 40) yaptığı çalışmasında 3000 TL'nin altında geliri olan ailelerin düşmanlık, red ve ebeveyn kabul-ret (toplam skor) ölçeklerinden daha yüksek puanlar aldıkları saptanmıştır. Raver (2003 Akt: Kaplan, 2005, s. 129) ise aile gelir düzeyi düşük olan annelerin çocuklarına karşı ilgi yardım ve çocuklarının bakım ihtiyaçlarını karşılamada yetersiz davrandıklarını belirtmiştir benzer şekilde Haktanır ve Baran (1998, s. 138) gelir düzeyi düşük ailelerde ebeveynlerin çocuklarına karşı cezalandıııı, kısıtlayıcı, istismar ve ihmal eden tutumlar sergilediklerini gelir düzeyinin yükselmesi ile birlikte bu tür olumsuz davranışların azaldığını belirtmiştir. T.C- Başbakanlık Aile Araştırma Kurumu (1998), ailenin gelir düzeyi düştükçe annenin çocuğa karşı daha çok şiddet içeren davranışlarda bulunduğunu belirtmiştir. Özdiker (2002, s. 111), annenin çocuğunu kabul ve ret davranışının ekonomik düzeyi göre değiştiğini ve ekonomik düzeyi yüksek olan annelerin çocuklarını daha çok kabul ettiklerini belirtmiştir. Hill, Bush ve Roosa (2003) ise ailenin gelir düzeyinin annenin çocuğuna gösterdiği kabul düşmanlık ve annenin depresyon durumunu etkilediğini belirtmiştir. Bu çalışmada annenin gelir düzeyi ile çocuğunu kabul-ret düzeyi arasında bir farklılaşma bulunamaması beklenmeyen bir sonuçtur. Çünkü ailenin gelir düzeyi çocuğuna bakım verebilme gücünü büyük oranda etkilemesi beklenir. Aile çocuğunun maddi ihtiyaçlarını karşılayabildiği ölçüde kendini yeterli hissedecektir. Özel gereksinimli bir çocuğun normal gelişim gösteren bir çocuğa göre maddi ihtiyaçları çok daha fazla ve ağırdır. Eğer çocuğun bedensel yetersizliği varsa geçireceği operasyon masrafları, fizik tedavi masrafları, görme, işitme yetersizliği varsa yine operasyon ve cihaz masrafları, eğitim masrafları ailenin maddi yükümlülügünü artırmaktadır. Aile maddi olarak bu yükün altından kalkamayacağını düşünürse veya kalkamadığını görürse, çaresizliğe düşebilir, çocuğunu reddetme eğilimi gösterebilir, kabullenme sürecinde zorlanabilir. Çünkü aileye göre gelir düzeyleri yüksek olsaydı, hem çocukları için gerekli tüm tedavi ve eğitim masraflarını karşılayabilecekler hem de yaşam standartlarını değiştirmeden yaşamaya devam edebilecekleri düşüncesi hakim olabilir. Bu sebeple araştırmada çıkan sonuç beklenmeyen bir sonuçtur.

Araştırmanın beşinci alt amacı olan özel gereksinimli çocuğa sahip annelerin Tanrı algıları ve umutsuzluk düzeyleri arasında ilişki olup olmadığına dair bulgular tartışılmışıı. Çalışma bulgularına göre annelerin Tanrı algısı ve umutsuzluk düzeyi arasında anlamlı bir ilişki bulunmuştur. İki değişken arasında negatif yönlü bir ilişki olup, bireyin Tanrı algısı arttıkça umutsuzluk düzeyi azalmaktadır. Sevgi ve korku yönelimli tanrı algılarının umutsuzluğu olumsuz yönde etkilediği görülmektedir. Bununla birlikte umutsuzluğu etkileme boyutunda düşük bir farkla da olsa korku yönelimli Tanrı algısının, sevgi yönelimli Tanrı algisından daha fazla etkilemektedir. Benzer bir sonuç bulan Smith, McCullough ve Poll (2003 Akt: 
Ceylan, 2018, s. 144) yaptı̆̆ bir çalışmada psikolojik iyi oluşun artması ile beraber zaten birbiriyle pozitif ilişkili olan olumlu dini başa çıkma ve sevgi yönelimli Tanrı algısının da artması beklenmektedir. Kaya'nın (2018, s. 82) araştırma bulgularına göre, kaygı düzeyi düşük olanların, kaygı düzeyi yüksek olanlara göre Tanr1 algisı daha olumludur. Subaşı (2012, s. 121) olumlu bir Tanr1 algisı kayg1 düzeyi seviyesini düşürdügünü belirtmektedir. Farklı bir çalışmada Ceylan (2018, s. 150) psikolojik iyi oluş ve dini başa çıkma tarzları ile ilgili yaptığı çalısmada Tanrı algısı, psikolojik iyi oluş ve dini başa çıkma tarzları arasında ise anlamlı bir fark bulamamıştır. Diğer araştırma bulguları, çalışma sonucunu desteklemektedir. Tanrı algisının, dini inancin, Tanrı'ya güven duymanın ve onun tarafindan sevilme düşüncesi inancı, bireylerin geleceğe dair olumsuz duygu ve beklentilerini, kaygılarını umutsuzluklarını değiştirmesi beklenen bir sonuçtur. Çünkü Tanrı onlara göre, yüce kutsal bir güçtür ve her şey onun elindedir. O tüm canlıları korur ve kollar. Bu inanç bireylerin geleceğe yönelik umutlarını artırmaktadır.

Araştırmanın altıncı alt amacı olan özel gereksinimli çocuğa sahip annelerin umutsuzluk düzeyleri ve çocuğunu kabul- ret düzeyleri arasında ilişki olup olmadığına dair bulgular tartışılmıştır. Çalışmaya göre özel gereksinimli çocuğa sahip annelerin umutsuzluk düzeyi ve çocuğunu kabul-ret düzeyleri arasında pozitif yönlü önemli bir ilişki bulunmuştur. Bu bulgu, katıllımcıların umutsuzluk düzeyi yükseldikçe ebeveyn kabul-ret (ebeveyn ret) düzeyinin de yükseldiğini göstermektedir. Gelecekten beklenti ile ebeveyn kabul-ret düzeyi arasında istatistiksel olarak anlamlı bir ilişki bulunamamışır. Buna karşılık motivasyon kayb1 ve umut alt boyutları, ebeveyn kabul-ret düzeyini olumlu yönde etkilerken, umut değişkenin motivasyon kaybından daha etkili olduğu söylenebilmektedir. Bunun anlamı katılımcıların motivasyon kayb1 ve umut düzeyleri yükseldikçe ebeveyn kabul-ret düzeyleri de yükselmektedir. Benzer çalışmalara bakıldığında Muştu Eren (2018, s. 42) ebeveynlerin yaşam doyumu ölçeğinden aldıkları puanlar artıkça, ebeveynlerin sıcaklık-şefkat, düşmanlık, ihmal, red ve ebeveyn kabul-red ölçeklerinden aldıkları puanlarda düşmekte olduğu saptanmıştır. Çalışmada çıkan sonuca göre annenin geleceğe dair umutlu olması, çocuğunu kabul etme düzeyini olumlu yönde etkilemesi beklenebilir. Çünkü anne, özel gereksinimli çocuğunun gelecekteki yaşamını planlamak, çocuğunu hayata hazırlamak ve ihtiyaçlarını kendi giderebileceği düzeye gelecek şekilde eğitimini planlamak ister. Buna dair beslediği umut, çocuğuna sıcaklık sevgi ilgi alaka olarak yansiyabilir.

Araştırmanın yedinci alt amacı olan özel gereksinimli çocuğa sahip annelerin Tanrı algıları ve çocuğunu kabul- ret düzeyleri arasında ilişki olup olmadığına dair bulgular tartısılmıştır. Özel gereksinimli çocuğa sahip annelerin Tanr1 alg1sı ve çocuğunu kabul-ret düzeyleri arasında anlamlı bir ilişki bulunamamıştır. Literatürdeki araştırmalara bakıldığında, Paterson (1975); Weisner, Beizer ve Stolze 1991); Wrigley ve LaGory (1994); Bennett, Deluca ve Allen (1995); Rehm (1999), dini inanç sistemleri, biçimlendirilmiş dini uygulamalar dışında, kabullenmeyi ve ailelere engelliliği anlamlandırmalarında yardım etmeyi teşvik eder. Fakat engelli üyelere sahip ailelerde dindarlığın işlevi olumsuzdan ziyade daha olumlu yöndeyken (Rogers, Dulan ve Blacher, 1995) aileler dini inançlarının yetersiz olduğu ya da yaptıkları bir yanlışın cezasını çektikleri algısını içeren ileri düzeyde bir stres de yaşayabilirler (Akt: Treloar, 2012, s. 214).

Araştırmanın sekizinci alt amacı olan özel gereksinimli çocuğa sahip annelerin umutsuzluk düzeyi, Tanrı algısı ve çocuğunu kabul-ret düzeyleri arasında anlamlı düzeyde ilişki olup olmadığına dair bulgular tartışılmıştır. Araştırmanın en önemli bulgularından biri olarak; Tanrı algısı umutsuzluğu olumsuz etkilerken, umutsuzluk, ebeveyn kabul-ret düzeyini olumlu yönde etkilemektedir ve Tanrı algisı ile ebeveyn kabul-ret arasında bir ilişki yoktur. Bu bulgulara göre, umutsuzluk değişkeninin, tanrı algısı ile ebeveyn kabul-ret değişkenleri arasında bir mediatör etkisinden söz edilebilmektedir. Mediatör (Ilımlaştırıcı) Değişken; Bağımlı ve bağımsız değişkenler arasında gözlemlenen bir ilişkinin gücünü ve değişkenlerle farklı ilişkisi olması sebebiyle ortadan kaldıran veya azaltan değişken olarak tanımlanır. Mediatör değişken hem bağımlı değişkene hem de bağımsız değişkene etki eder. Literatürde bu üç değişkenin birbirleriyle ilişkisinin incelendiği herhangi bir araştırmaya rastlanmamıştır (Gödeş, 2019). Çalışma sonucu yorumlandığında Tanr1 alg1sı yükseldikçe umutsuzluk düzeyi düşmektedir. İnsanlar kendilerinden daha güçlü ve daha büyük bir varlığa sığınmaya ve onun kendilerini korumasına ihtiyaç duyarlar. İslamiyet inancının yaygın olduğu toplumumuzda insanlar Allah'a inanmanın, ona teslim olmanin, onun emir ve yasaklarına uyarak huzurlu ve mutlu yaşanabileceğine dair inançları, onları geçmişe şükretme geleceğe de dua ile umutla bakma eğilimini gösterirler. Özel gereksinimli bir çocuğa sahip olmak, onlara göre geleceğe dair umutsuzluk sebebi değil, Allah'ın kendilerini ödüllendireceği bir umut kapısıdır. İslamiyet' te umutsuzluğa, düşmek doğru değildir. Bu sebeple Tanr1 algılar1 yüksek olan bireylerin, umutsuzluk düzeylerinin düşük olması beklenen bir sonuçtur. Bulgu devamında da umutsuzlukla birlikte ebeveyn reddi de düşmektedir. Umutsuzluk düzeyinin düşmesi, gelecekten olumlu beklentilere sahip olmak anlamına geldiği için anneler 
geleceğe dair pozitif düşünceler geliştirirler. Bu düşüncelere göre gelecekte olumlu güzel bir yaşantıları olacaktır. Bunun bilincinde ve inancında olan annelerde çocuğuna karşı olumlu duygular gelişir, dolayısıyla çocuğunu reddetme düzeyi düşer. Sonuç olarak, Tanrı inancı arttıkça umutsuzluk azalıyor, onunla birlikte ebeveyn reddi de azalıyor. Ya da tanrı algisı azaldıkça umutsuzluk artıyor, onunla birlikte ebeveyn reddi de artiyor diyebiliriz.

Araştırma bulgularından elde edilen sonuçlara göre uygulamacılar ve ileri araştırmalar için öneriler: Özel gereksinimli çocuğa sahip olan annelerin demografik özelliklerine göre Tanrı algıları, umutsuzluk düzeyleri ve kabul ret düzeyleri ölçülmüş olup, anneleri farklı demografik özelliklerine düşük Tanrı alg1larına, yüksek umutsuzluk düzeyine ve/veya yüksek Ret, düşük kabul düzeylerine sahip oldukları görülmektedir. Annenin psikolojik sağllğı ve sürekli iyi olma hali anne-çocuk, anne- baba ve aile içi iletişimi olumlu yönde etkileyeceği için annelere yönelik, uzman eğitimciler tarafından rehberlik ve danışmanlık hizmetleri, aile eğitimi programlarının düzenlenmesi önerilebilir. Toplumumuzda bireylerin Tanrı algıları arttıkça, umutsuzluk düzeylerinin azaldığı görüldügünden sorunlarla başa çıkma düzeylerinin de artacağ1 düşünülerek ailelere yönelik doğru dini eğitimler verilerek olumlu Tanrı algılarının artırılması sağlanabilir. Ailelerin çocuklarını kabul etme sürecini dolaylı yoldan etkileyeceği düşünüldügünden, Din eğitimi, olumlu Tanrı algısını artırmaya yönelik eğitimler verilmesi önerilebilir. Bu araştırma özel gereksinimli çocukların bakım yükünü babalara göre daha çok üstlendiği bilinen anneler üzerinde yapılmıştır. Babanın umutsuzluk düzeyi Tanrı algısı ve çocuğunu kabul reddinin ölçülmesi de çalışmayı desteklemesi açısından önemlidir. Bu sebeple babalar üzerinde bir çalışma önerilebilir. Bu çalışma özel gereksinimli bireylerin engel gruplarını ayırmadan bütün olarak ele alınmıştır. Yeni bir çalışmada birey; engel gruplarını ayrılarak tek bir çalışmaya da ayrı ayrı çalışmalar şeklinde araştırılabilir.

\section{Etik Beyan}

"Özel Gereksinimli Cocuğa Sabip Annelerin Umutsuحluk Düzeyi Tann Algisı ve Cocuğunu Kabul-Ret Düreyleri Arasındaki İlişkinin Incelenmesi" başlıklı çalışmanın yazım sürecinde bilimsel kurallara, etik ve alıntı kurallarına uyulmuş; toplanan veriler üzerinde herhangi bir tahrifat yapılmamış ve bu çalışma herhangi başka bir akademik yayın ortamına değerlendirme için gönderilmemiştir. Bu araştırmanın verileri 01.01.2020 tarihinden önce toplandığı için etik kurul kararı zorunluluğu taşımamaktadır.

\section{Kaynakça}

Adler, A. (2014). Insan tabiatın tanıma (Çev: A. Yörükan). İstanbul: Türkiye İş Bankası Kültür Yayınları.

Akarsu, Ö. (2014). Zibinsel yetersiz cocuklarn aile yükü, özbakım becerileri, annelerinin yaşam doyumu ve etkileyen faktörler (Yüksek Lisans Tezi ). Trakya Üniversitesi, Sağlık Bilimleri Enstitüsü, Edirne.

Akandere, M., Acar M. ve Baştuğ, G. (2009). Zihinsel ve fiziksel engelli çocuğa sahip anne ve babaların yaşam doyumu ve umutsuzluk düzeylerinin incelenmesi. Selçk Üniversitesi Sosyal Bilimler Enstitüsü Dergisi, 22-32.

Aktaş, Y. (1994). Çalışan anne ve çocuğu, Yaşadıkça Eğitim Dergisi, Sayı: 36.

Akyüz, Z. (2010). Gençlerde benlik saygisı ve tanr tasavvuru (Yüksek Lisans Tezi). Marmara Üniversitesi, Sosyal Bilimler Enstitüsü, İstanbul.

Alçelik, Z. (2013). Yaşllık döneminde tanr tasavvuru ve benlik saygısı (Yüksek Lisans Tezi). Marmara Üniversitesi, Sosyal Bilimler Enstitüsü, İstanbul.

Anjel, M. ve Erkman, F. (1993). The transliteral equivalence, reliability and validity studies of the parental acceptance-rejection questionnaire (parq) mother-form: A tool for assessing child abuse. International Society for Prevention of Child Abuse\& Neglect-Regional Conference, Boğaziçi University, İstanbul.

Arslan, H. (2010). Algzlanan ebeveyn kabul ve reddinin mizaç ve karakter özelliklerine etkisi (Yüksek Lisans Tezi). Ege Üniversitesi, Sosyal Bilimler Enstitüsü, İzmir.

Aydın, Ö. (2011). Yaşamı sürdürmede dini inancın rolü (Doktora Tezi ). Ankara Üniversitesi, Sosyal Bilimler Enstitüsü , Ankara.

Bailey, D. B. ve Simeonsson, R. N. (1988). Assessing family stres and needs, family assssment in early intervation. Columbus, OH: Merrill. pp. 207-228.

Beck, A. T., Weissman, A., Lester, D.ve Trexler, L. (1974). The measurement of pessimism: The hopelessness scale. University of Pennsylvania, Journal of Consultingand Clinical Psychology, 42(6), 861.

Bennett, T., Deluca, D. A. ve Allen, R. W. (1995). Religion and children with disabilities. Journal of Religion and Health, 34, 301-312.

Campo, A. T. ve Rohner, R. P. (1992). Relationships between perceived parental acceptance rejection, psychological adjustment, and substance abuse among young adults. Child Abuse And Neglec. 16(3), 429-440.

Ceylan, U. E. (2018). Ölümlülük bilincinin dini başa çıkma, tanr algısı, ölüm kaygısı ve psikolojïk iyi olma ile ilişkisi (Doktora Tezi). Ankara Üniversitesi, Sosyal Bilimler Enstitüsü, Ankara. 
Ceylan, R. (2004). Entegre eğitime katılan ve katılmayan engelli çocuklarn annelerinin depresyon ve umutsuzluk düzeylerinin incelenmesi (Doktora Tezi). Ankara Üniversitesi, Fen Bilimleri Enstitüsü, Ankara.

Çınar, M. (2015). Yetişkin ve yaşlılarda tanrya bağlanma taræ̨ ve ölüm kayglsı iliş̧kisi üzerine bir araştırma (Yüksek Lisans Tezi). Atatürk Üniversitesi, Sosyal Bilimler Enstitüsü, Erzurum.

Darıca, N., Pișkin Ü. ve Gümüşçü, Ș. (1994). Otizm ve otistik çocuklar. Ankara: Basım Grafik.

Delitay, H. (2009). Engelli cocuk annelerinin çocuklarm reddetme davranıslar (Yüksek Lisans Tezi). Gazi Üniversitesi, Eğitim Bilimleri Enstitüsü, Ankara.

Dere, N. (2009). Annelerin otistik çocuklarm kabul etmeleri ile otistik çocuklarn kardeșlerinin kardeşlerini kabulü arasındaki iliskkinin incelenmesi (Yüksek Lisans Tezi). Marmara Üniversitesi, Eğitim Bilimleri Enstitüsü, İstanbul.

Dilbaz, N. ve Seber, G. (1993). Umutsuzluk kavramı: Depresyon ve intiharda önemi. Kriz Dergisi, 1(3), 134-138.

Durak, A. ve Palabıyıkoğlu, R. (1994). Beck umutsuzluk ölçeği geçerlik çalışması. Križ Dergisi: 2(2), 311-319.

Erkan, S. ve Toran, M. (2004). Alt sosyoekonomik düzey annelerin çocuklarını kabul ve reddetme davranışlarının incelenmesi (Diyarbakır İli Örneği). Hacettepe Üniversitesi, Eğitim Fakültesi Dergisi, 27, 91-97.

Erkman, F. ve Varan A. (2004). Sicaklık boyutu: Ebeveyn kabul ve reddi kuramı, ölçüm araçları ve araştırma bulguları. XIII. Ulusal Psikoloji Kongresi. Bilgi Üniversitesi, İstanbul.

Eş, A. (2013). Zibinsel engelli bireye sabip annelerin çocuklarm kabullenişleri ile umutsuðluk düzeylerinin incelenmesi (İstanbul İliSancaktepe Örneği) (Yüksek Lisans Tezi ). Yeditepe Üniversitesi, Sosyal Bilimler Enstitüsü, İstanbul.

Fırat, S. (2000). Zibinsel ve otistik özürlü çocuklarn annelerinde kaygz, depresyon, aleksitimi ve genel psikolojik değerlendirme (Yüksek Lisans Tezi). Çukurova Üniversitesi, Sosyal Bilimler Enstitüsü, Adana.

Fromm, E. (2004). Psikanaliz ve din (Çev: A. Arıtan). İstanbul: Arıtan Yayıncılık.

Gödeş, M. (2019). Klinik psikolojisi, https://www.guncelpsikoloji.net/arastirma-yontemleri/ilimlastirici-mediatordegisken-nedir-h6323.html.

Güler, Ö. (2007a). Tanrı Alg1sı Ölçeği (TA): Geçerlik ve güvenlik çalışması. Ankara Üniversitesi Sosyal Bilimler Enstitüsü, Illahiyat Fakültesi Dergisi, 48(1), 123-133.

Güler, Ö. (2007b). Tanr’ya yönelik atıflar, benlik algısı ve günabkarlk duygusu (Yetişkin Örneklem) (Yüksek Lisans Tezi). Ankara Üniversitesi, Sosyal Bilimler Enstitüsü, Ankara.

Güngördü, M. (2001). Allah' a atfedilen özellikler ile depresyon arasındaki ilişki üzerine bir araştırma (Yüksek Lisans Tezi). Dokuz Eylül Üniversitesi, Sosyal Bilimler Enstitüsü, İzmir.

Haktanır, G. ve Baran, G. (1998). Gençlerin benlik saygısı düzeyleri ile anne baba tutumlarını algılamalarının incelenmesi. Cocuk ve Genclik Ruh Sağh̆ğ Dergisi, 5(3), 134-141.

Hill, N. E., Bush, K. R. ve Roosa, M. V. (2003). Parenting and familly socialization strategies and children's mental healt : low-ncome mexican- american and euro-american mothers and children. Child Development, 74(1), 189204.

Homan, K. J. ve Cavanaugh, B. N. (2013). Perceived relationship with God fosters positive body image in college women. Journal of Health Psychology, 18(12), 1529-1539.

Hood Jr, R. W., Hill, P. C. ve Spilka, B. (2009). The psychology of religion: An empirical approach. New York \& London: Guilford Press.

Kaplan, Y. (2005). 3-12 Yaş lösemili çocuğu olan annelerin hastaliğın teşhis ve tedavi sürecinde çocuğunu kabul ve red davranuşlar ve depresyon düreylerinin incelenmesi (Yüksek Lisans Tezi). Hacettepe Üniversitesi, Sosyal Bilimler Enstitüsü, Ankara.

Karaçengel, F. J. (2007). Zibinsel engelli çocuğa sabip anneler ile sağhlkh çocuğa sabip annelerin, atılganllk ve sucluluk-utans düzeyleri açısından karşılasstırlması (Yüksek Lisans Tezi). Maltepe Üniversitesi, Sosyal Bilimler Enstitüsü, İstanbul.

Karasar, N. (2007). Bilimsel araştırma yöntemleri (15.Baskı). Ankara : Nobel Yayınları.

Kaya, F. (2018). Imam hatip lisesi ögrencilerinde tanr algısı ve kaygz ilişkisi üzerine bir araştırma (Yüksek Lisans Tezi). Atatürk Üniversitesi, Sosyal Bilimler Enstitüsü, Erzurum.

Koç, A. (2011). Üniversite ögrencilerinde tanr tasavvuru, benlik algısı ve öfke yaşantısı (Yüksek Lisans Tezi). Ankara Üniversitesi, Sosyal Bilimler Enstitüsü, Ankara.

Kula, T. (2012). Ergenlerde öfke duygusu; benlik algısı, tanr algısı, suçluluk ve utanc duygular açısından bir değerlendirme (Diyarbakır Örneklemi) (Yüksek Lisans Tezi). Ankara Üniversitesi, Sosyal Bilimler Enstitüsü, Ankara.

Mehmedoğlu, U. A. (2011). Tanryı tasavvur etmek. İstanbul: Çamlıca Yayınları.

Metin, M. (2014). Kuramdan uygulamaya eğitimde bilimsel araştırma yöntemleri. Ankara: Pegem Akademi Yayıncilik.

Muştu, Eren, T. (2018). Zibinsel engelli ve / veya otižm tanısı olan çocuğa sabip ebeveynlerin çocuklarm kabul red düzeyi ve yaşam doyumlar arasindaki ilişkei (Yüksek Lisans Tezi). Beykent Üniversitesi, Sosyal Bilimler Enstitüsü, İstanbul.

Murphy, P. E., Ciarrocchi, J. W., Piedmont, R. L., Cheston, S., Peyrot, M. ve Fitchett, G. (2000). The relation of religious belief and practices, depression, and hopelessness in persons with clinical depression. Journal of Consulting and Clinical Psychology, 68(6), 1102.

Noffke, J., L. ve McFadden, S., H., (2001). Denominational and age comparisons of God concepts. Journal for the Scientific Study of Religion, 40(4),747- 756.

Olçay, G. U. (2016). Alkol ve madde bağımlihğ tedavisi gören bireylerde algilanan sosyal destek ve umutsuzluk düzeyi arasındaki ilişkinin incelenmesi (Yüksek Lisans Tezi). Haliç Üniversitesi, Sosyal Bilimler Enstitüsü, İstanbul.

Özdiker, J. B. (2002). Dikkat eksikliği hiperaktivite bozukluğu olan çocuklarn anneleri ile iliskilerini algulamalarnile annenin cocuğunu kabullenme ve reddetme davramıslarna ait algilamalar arasindaki ilisksinin incelenmesi (Yüksek Lisans Tezi). Marmara Üniversitesi, Eğitim Bilimleri Enstitüsü, İstanbul. 
Öztürk Can, H. ve Aksel E. Ş., (2017). Ebeveyn kabulü/reddi ile ebeveyn uygulamalarilişkisi ve etkileyen faktörler. Humanities Sciences (NWSAHS), 12(1), 35-51.

Paterson, G. W. (1975). Helping your handicapped child. Augsberg Publishing House, Minneapolis, MN.

Pektaş, İ. ve Özgür G. (2005). İlköğretim öğrencilerinin anneleri ile olan ilişkilerini algılayışları ve bu ilişkiyi etkileyen etmenlerin incelenmesi. Ege Üniversitesi, Hemşirelik Yüksekokulu Dergisi, 21(2), 13-27.

Raver, C. (2003). The role of employment in predicting depressive symptoms and parenting among ldw-income families. Child Development, 74(6), 1720-1736.

Rohner, R. P. Saavedra, J. M. ve Granum, E. O. (1978). Development and validation of the parental acceptancerejection questionnaire: Test-manual. Washington, D. C. : American Psycholog. Ass., Journal Suppl. Abstract Service.

Rohner, R. P. And Khaleque, A. (2005). Handbook Fort He Study of ParentalAc-Ceptanceand Rejection, Rohner Research Publications, USA.

Rogers-Dulan J. ve Blacher J. (1995). African american families, religion, and disability: A conceptual framework. Mental Retardation, 33, 226-238.

Sailor, D.(2004). Supporting children in their home, school and community. Boston: Pearson Press.

Sarpdağı, Y. (2018). Epilepsili çocuğa sabip ebeveynlerin bakım yükü ve umutsuə̣luk düreyinin incelenmesi (Yüksek Lisans Tezi). Atatürk Üniversitesi, Sağlik Bilimleri Enstitüsü, Erzurum.

Seber, G., Dilbaz, N., Kaptanoğlu, C. ve Tekin, D. (1993). Umutsuzluk ölçeği: Geçerlilik ve güvenirliği. Križ Dergisi, 1(3), 139-142.

Smith, T. B., McCullough, M. E. ve Poll, J. (2003). Religiousness and depression: evidence for a main effect and the moderating influence of stressful life events. Psychological Bulletin, 129(4), 614.

Subaşı, H. (2012). Üniversite ögrencilerinin tanr ile ilişkilerinin bağlanma kuramı açsındam değerlendirilmesi (Yüksek Lisans Tezi). Marmara Üniversitesi, Sosyal Bilimler Enstitüsü, İstanbul.

Şimşek, D. (2015). Otistik çocuğu olan annelerin algiladiklari sosyal desteğe göre umutsuحluk düzeylerinin incelenmesi (Yüksek Lisans Tezi ). Beykent Üniversitesi, Sosyal Bilimler Enstitüsü, İstanbul.

Tabachnick, B. G. ve Fidell, L. S. (2013). Using multivariatestatistics (Sixthedition). Pearson Education, United States.

T.C. Başbakanlık Aile Araştırma Kurumu (1998). Aile içinde ve toplumsal alanda şiddet. Ankara: T.C. Başbakanlık Aile Araştırma Kurumu Yayınları.

Tekin, H. (2017). Otizmli çocuklara sabip babalarn evlilik yaşam ve çocuğunu kabul red düzeylerinin eğitim açısindan incelenmesi (Yüksek Lisans Tezi). Yeditepe Üniversitesi, Eğitim Bilimleri Enstitüsü, İstanbul.

Tezel-Şahin, F. ve Özyürek, A. (2008). 5-6 yaş grubu çocuğa sahip ebeveynlerin demografik özelliklerinin çocuk yetiştirme tutumlarına etkisinin incelenmesi. Türk Eğitim Bilimleri Dergisi, 6(3), 395-414.

Türkoğlu, N. (2001). Zibinsel Engelli çocuklarn anne, baba ve kardeşlerinin kayg düreylerine etki eden etmenlerin incelenmesi (Yüksek Lisans Tezi). Hacettepe Üniversitesi, Eğitim Fakültesi, Ankara.

Treloar, L. L. (2012). Engellilik, dini inançlar ve kilise: engelli yetişkinlerin ve aile bireylerinin deneyimleri (Çev: M. Bahçekap1l1). İstanbul Üniversitesi İlabiyat Fakültesi Dergisi, 27, 211-230.

Uysal, V., Batan, S. N., Baş, S. ve Zafer, H. (2014). Ergenlerin tanrı algılarıla sosyal kaygı ve umut düzeyleri arasındaki ilişkiler. Marmara Üniversitesi Öneri Dergisi, 221-237.

Weisner, T. S., Beizer, L. ve Stolze, L. (1991). Religion and families of children with developmental delays. American Journal on Mental Retardation, 95, 647-662.

Wrigley, M. ve LaGory, M. (1994). The role of religion and spirituality in rehabilitation: a sociological perspective. Journal of Religion in Disability and Rehabilitation, 1, 27-40.

Yakmaz Basilgan, F. (2012). Annelerin kabul-red düzeyi ile çocuklarn davranıș sorunlar arasindaki iliskinin incelenmesi (Yüksek Lisans Tezi). Arel Üniversitesi, Sosyal Bilimler Enstitüsü, İstanbul.

Yamaç, A. (2011). Zibinsel engelli çocuklarm ebeveynlerinin, çocuklarm kabul-red düzeyi ile çocuk yetistirme tutumlar arasındaki ilişkinin incelenmesi (Yüksek Lisans Tezi). Marmara Üniversitesi, Eğitim Bilimleri Enstitüsü, İstanbul.

Yavuzer, H. (2000). Okul çă̆ çocuğu. Ankara: Remzi Kitabevi.

Yıldırım, B. ve Keskinkılıç Kara, S. B. (2017). Öğretmenlerin umutsuzluk düzeylerinin incelenmesi. Ulakbilge, 5 (11), 571-587.

Yıldız Y. (2007). Tedavi içinde: Epilepsi el kitabı (Handbook of Epilepsy) (3. Baskı). (Brownw TR, Holmes, GL.). Ankara: Güneş Tip Kitabevleri, 138-162.

\section{EXTENDED ABSTRACT}

When a baby considered being healthy is born, the family experiences great happiness and excitement. However, with the family learning that he/she is a baby with special needs and even has disabilities, the first reactions of mothers especially are shock, rejection, sadness, anger, guilt, anxiety, momentary emotional crises; evade the issues, disappointment, decreased self-esteem, future anxiety and despair (Darica, 1994, p. 145). While the concept of hope draws attention to the expectation aspect about the future, negative thoughts prevail in despair. Therefore, despair is considered as not having expectations for the future (Stonlet, 1969 Cited in: Olcay, 2016, p. 51). Accordingly, a person who is pessimistic and has no hope for the future believes that nothing will improve, he/she will not be 
successful in any field, he/she will not be able to realize his/her goals for the future, and worst of all, he/she will never be able to solve his/her problems (Yildırım et al. 2017, p. 574).

There are spiritual concepts that families take refuge in to cope with negative emotions, to control their levels of despair, stress, helplessness and anxiety, and to continue their lives with positive emotions. The strong spiritual shelter in Turkish society is the parents' perception of God. According to Adler (2014, p. 42), perception is a spiritual function that transcends a simple physical event, enables a person to reach the most extensive and comprehensive result about his/her inner life. Trust in believing something nurtures the perception and belief of God in humanistic religions. Faith is a system that is shaped by one's own feelings, thoughts and experiences (Fromm, 2004 Cited in: Güler, 2007a, p. 12).

Society's or parents' perception of God affects their evaluation of positive and negative experiences. The perception of God is related to how an individual learns and makes sense of God. Every individual who knows the concept of God can attribute certain features to God in his/her mind. These features, which can be positive or negative, are the individual's attributions to God (Güler, 2007a, p. 18). Homan and Cavanaugh (2013, p. 1531) stated that attributions to God do not affect the life of the individual positively, on the contrary, some features attributed to God are useless for the individual. The individual's perception of God is a problem if it makes his/her life difficult and makes him/her feel helpless and guilty. Likewise, if the negativities encountered in life are perceived as evidence of God's displeasure, this may cause distress for the individual (Ceylan, 2018, p. 49).

On the other hand, some of the perceptions of God are seen to benefit the psychological and social life of the individual. It has been revealed that individuals who have a love and trust oriented God perception have more reasons to maintain life, hold on to life, and adhere to their beliefs. Accepting God as a safe haven to cope with the stress experienced by the individual and taking refuge in the mercy of God makes the individual think positively about the life.

The family is the first institution where the child socializes. Parents' readiness for the birth of a new baby, their multifaceted expectations from the baby and the future of the baby have an effective role in the baby's first impression of the environment and the baby's social-emotional development. The individual is born and joins the family, and his/her first interaction is with his/her mother. Any physical, social and emotional relationship of the baby with his/her mother will significantly affect the baby's multidimensional development and therefore every stage in his/her future life (Sailor, 2004 Cited in: Yilmaz, \& Basilgan, 2012, p. 1).

Families need both time and support in the process of accepting the situation and adapting to the new situation after their children, who are expected to be born healthy, are born with developmental disabilities. Families may experience low expectations for the future, despair, guilt or look for someone to blame and rejection process. Acceptance is a parental behavior that reflects the emotional relationship between parents and children. Parents' acceptance of their child supports positive behaviors towards $\mathrm{him} /$ her. These behaviors are to treat their child with love, to establish positive contact, to hug the child, to take care of the child's wishes and needs. On the other hand, the behavior of rejecting the child is the opposite of positive behavior in accepting child. Reflection of negativities such as not being interested in the wishes and needs of the child, exclusion, criticizing, comparing, not approaching him/her with love is related to the behavior of rejecting (Yavuzer, 2000, p. 59).

This study examines the three concepts together in order to analyze information about the level of despair, God perceptions, and acceptance-rejection levels of parents with special needs children and to analyze information on how they affect each other. Compared to other members of the family, the mother takes care of the individual with special needs and takes care of all their needs. Determining the mother's level of despair, perception of God, and acceptance-rejection of her child and examining the relationship between them will make a significant contribution to the literature.

This aim of this study analyzes the relationship between the mothers of the children with special needs and mothers' hopelessness level and perception of God, as well as parental acceptance-rejection level. The method of the research was determined as the relational scanning model. This study also aims to research the relationship between the variables such as mothers' ages, education level, employment status, income level and the mothers' hopelessness level, perception of God, and parental acceptancerejection level. To get demographic information about the mothers, Demographic Information Form, Perceptions of God Scale, and Parental Acceptance-Rejection Scale has been used. This research covers 
the mothers of the children with mild, moderate, and high level of special needs. These children take education in the private educational institutions and the private education application centers in Sivas city center. Data of this research has been collected from 195 mothers.

When looked at the relationship between hopelessness level and the perceptions of God of the mothers of the children with special needs, mother's perception of God tend to increase conversely to their hopelessness. According to the relationship between the hopelessness level and parental acceptancerejection level of mothers of the children with special needs, this study also determines that as the hopelessness level of mother increases, the level of their acceptance-rejection increases as well. Also, the relationship between perceptions of God and parental acceptance of mothers of the children with special needs does not prove any meaningful relationship. One of the significant outcomes of this research is that perception of God has negative impact on hopelessness while the hopelessness affects parental acceptance-rejection positively, and there is no relationship between perception of God and the parental acceptance and rejection. 